\title{
Divorce and the Displaced Homemaker: A Discourse on Playing with Dolls, Partnership Buyouts and Dissociation Under No-Fault
}

\author{
Cynthia Starnes $\dagger$
}

\section{Table of Contents}

I. The Problem ....................... 72

A. The Role-Kinder, Küche, Kirche ........ 73

B. The "Liberation"-_Equality" for the Homemaker ........................ $\quad 76$

C. The Reality-Economic Tragedy ......... 78

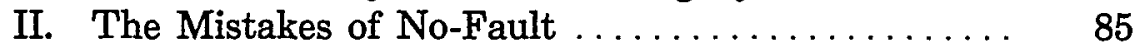

A. Property Distribution .............. 85

1. Minimal assets ................. 86

2. Palm-tree justice ................. 92

3. An Indiana story ................. 95

B. Maintenance ...................... 97

1. Discouraging support $\ldots \ldots \ldots \ldots \ldots \ldots . \quad 97$

a. The rehabilitation illusion $\ldots \ldots \ldots \ldots .97$

b. Another Indiana story ............. 99

2. Deferring to discretion............. 101

a. Judicial hostility - A Minnesota story 102

b. Judicial sympathy - A Wisconsin story........................ 104

III. The Quest for a Conceptual Basis for Maintenance. 106

A. The Search Thus Far .............. 106

1. The historical struggle-Marriage as contract or status? ................ 106

2. The UMDA model-The birth of partnership marriage .................. 108

$\dagger$ Associate Professor, Detroit College of Law. For their insightful suggestions, I am indebted to Alfred Conard, Ira Mark Ellman, E. Allan Farnsworth, Joan Krauskopf, John Larson, Robert McCormick, Ruth Thurman, Mary Pat Treuthart, Siegfried Wiessner, and R. George Wright. For their excellent research assistance, I owe much to Bridget Brown and Bryce Koth. For a summer stipend, I am grateful to the Detroit College of Law. 
3. Post-UMDA models-The return to contract ....................... 109

a. Protecting contractual interests ..... 109

(1) A restitution model . . . . . . . . . 110

(2) A reliance model ............. 111

(3) An expectation model ......... 113

b. Shunning a contract model ........ 115

B. A Contemporary Model - The Maturing of Partnership Marriage .................. $\quad 119$

1. An analogy-Concept, fact and law ..... 119

2. An application-Dissociation and buyout.. 124

3. A prediction-Ex ante effects ......... 127

a. Immediate effects . . . . . . . . . . . . 128

b. Long-term effects . . . . . . . . . . . 129

IV. Proposal for Legislative Reform . . . . . . . . . . 130

A. Maintenance as Buyout .............. 130

B. An Enhanced Earnings Model ............ 131

1. Valuing the enterprise $\ldots \ldots \ldots \ldots \ldots \ldots, 131$

a. Estimating future earnings . . . . . . . 132

b. Measuring enhancement .......... 133

2. Fixing the buyout price ............. 135

3. Modifying a buyout .............. 137

Conclusion .......................... 139 
Thy husband is thy lord, thy life, thy keeper, Thy head, thy sovereign; one that cares for thee, And for thy maintenance commits his body

To painful labour both by sea and land, To watch the night in storms, the day in cold, Whilst thou liest warm at home, secure and safe, And craves no other tribute at thy hands But love, fair looks and true obedience; Too little payment for so great a debt. ${ }^{1}$

Katherine in The Taming of the Shrew.

I felt a warm little glow under my rib cage. Someone thought I was a competent human being, not a pain in the butt who should mind her own business .... [I]t just felt good to have someone-some man-call up and think first that I should be working, not that I should stay home and play with dolls. ${ }^{2}$

V.I. Warshawski in Burn Marks.

Wifely submission is risky business in the 1990s. Gone is the day when a wife could depend on her husband's labor to maintain her at home, "secure and safe." Today is the day of divorce at will and equality rhetoric, which means that if her marriage ends, the homemaking wife ${ }^{3}$ will be catapulted into financial independence,

${ }^{1}$ William Shakespeare, The Taming of the Shrew, V:ii:151, in The Complete Works 59-60 (Oxford, 1986).

2 Sara Paretsky, Burn Marks 117 (Delacorte, 1990).

3 Throughout this Article, a homemaker is presumed to be female. The Bureau of Labor Statistics reported that in 1991, a total of 41.8 million women (married or unmarried) stayed out of the labor force for various reasons. Approximately 22.7 million of them did not want a job because they were "keeping house." An additional 1.2 million wanted a job, but did not look for one because of "home responsibility." By contrast, only 415,000 men stayed out of the labor force to "keep house," and only a "small number" did not look for work because of "home responsibility." Bureau of Labor Statistics, United States Dept of Labor, 39 Employment and Earnings, No 1 at 204, Table 35 (1992) ("Bureau of Labor Statistics"). See also National Displaced Homemakers Network, The More Things Change .. . A Status Report on Displaced Homemakers and Single Parents in the 1980s 59 (1990) (on file with U Chi L Rev) ("Status Report (1990)").

Based on similar 1983 statistics, Dean Marilyn Yarbrough concluded that a woman is 100 times more likely to be a displaced homemaker than a man. Marilyn Yarbrough, Disparate Impact, Disparate Treatment, and the Displaced Homemaker, $49 \mathrm{~L} \&$ Contemp Probs, No 4 at 107, 119 (1986). For a definition of displaced homemaker, see note 7. Even when a woman works outside the home, she is likely to undertake a disproportionately large share of homemaking chores. See note 11 and accompanying text. 
and probably financial ruin. Such is the 1990s price tag for choosing to "play with dolls."

This is not good news for approximately sixteen million married women who are not employed outside their homes because they are "keeping house." Seriously at risk are the heroines of the Betty Crocker culture, women who have already devoted their most career-productive years to homemaking and who, if forced into the labor market after divorce, suddenly will be viewed as modern dinosaurs. Non-wage-earning mothers of young children and many wage-earning wives whose responsibilities as primary caretakers limit their career choice and advancement face similar risks. If their marriages end, these women may learn the true meaning of "the divorce revolution"s as they are judged by divorce courts determined to implement the fashionable rhetoric that men and women are equal. Startling inequities have resulted, as judges ignore the realities of scant property and limited earning potential and adopt the legislative assumption that homemakers need minimal, if any, maintenance. The broad discretion vested in these judges then insulates each of their idiosyncratic decisions from meaningful appellate review. Homemakers whose divorces are not litigated are equally hard-hit as they negotiate or mediate within this disastrous judicial and legislative framework.

The few courts and legislatures that have acknowledged this situation have often responded in only a timid and tentative fashion. Concerned legal commentators have launched a bolder search for a theoretical basis for maintenance, which the clean-break philosophy of no-fault does not provide. This search has contributed to the American Law Institute's recent decision to draft a set of principles to guide family law. The Institute's work makes timely this examination of the problem.

4 See Barbara Stark, Divorce Law, Feminism, and Psychoanalysis: In Dreams Begin Responsibilities, 38 UCLA L Rev 1483, 1522 (1991) (little girls practice their role as nurturer through interminable play with dolls).

s Of 51.5 million wives in the United States in December, 1991, a total of 21 million were not in the labor force for various reasons. Approximately 16 million wives were not in the labor force because they were "keeping house." Bureau of Labor Statistics at 26 (cited in note 3).

- See generally Lenore J. Weitzman, The Divorce Revolution (Free Press, 1985). 
No-fault divorce laws are not alone responsible for the impoverishment of displaced homemakers. ${ }^{7}$ No-fault did not create the sex/gender system. ${ }^{8}$ Nor is no-fault responsible for the depreciation in marketable human capital that ordinarily accompanies homemaking. No-fault, however, exacerbates the effects of these factors by making divorce easier to obtain, ${ }^{9}$ thus increasing the number of women who lose their male buffer when they are financially vulnerable. Although the roots of this problem can be traced to the sex/gender system, elimination of that system is too slow a solution for the displaced homemaker. Her urgent problem demands a swift response.

In this Article, I advocate divorce law reform as an immediate response that will both ease current suffering and encourage future relaxation of gender roles. My proposal models marriage after contemporary partnership law, reconceptualizes divorce, and adopts a new vocabulary, suggested by recent drafts of the Revised Uniform Partnership Act. Under this contemporary partnership model, divorce occurs when a spouse dissociates from the relationship before

" Laurie Shields credits Tish Sommers with coining the term "displaced homemaker" in 1974. Laurie Shields, Displaced Homemakers: Organizing For A New Life ix (McGrawHill, 1981). The following definition appears in the Displaced Homemakers Self-Sufficiency Assistance Act ("DHSSAA"), Pub L No 101-554, § 3(3), 104 Stat 2751 (1991), codified at 29 USCA \& 2302(3) (West Supp 1991):

(3) The term "displaced homemaker" means an individual who has been providing unpaid services to family members in the home and who-

(A) has been dependent either-

(i) on public assistance and whose youngest child is within 2 years of losing eligibility under part A of title IV of the Social Security Act [42 U.S.C.A. \$ 601 et seq.], or

(ii) on the income of another family member but is no longer supported by that income, and

(B) is unemployed or underemployed and experiencing difficulty obtaining or upgrading employment.

- This system is described in Gayle Rubin, The Traffic in Women: Notes on the "Political Economy" of Sex, in Rayna R. Reiter, ed, Toward an Anthropology of Women 157, 168 (Monthly Review Press, 1975). Barbara Stark discusses the impact of the sex/gender system on the law of divorce in her helpful article. See Stark, 38 UCLA L Rev at 1494-1503 (cited in note 4).

- The ease with which a husband may dispose of his aging wife under no-fault is colorfully criticized in In re Marriage of Branter, 67 Cal App 3d 416, 136 Cal Rptr 635, 637 (1977):

A woman is not a breeding cow to be nurtured during her years of fecundity, then conveniently and economically converted to cheap steaks when past her prime .... -..

This has nothing to do with feminism, sexism, male chauvinism, or any other trendy social ideology. It is ordinary common sense, basic decency and simple justice. Contrary to Judge Gardner's suggestion, the financial devastation of homemakers under nofault is very much a feminist issue, since homemakers are almost always women. See note 3 and accompanying text. 
expiration of the term. Dissociation triggers the equal division of traditional marital property. In addition, a dissociated spouse receives the right to a buyout of her interest in any income-generating marital enterprise that continues after dissociation. Such a marital enterprise continues when the enhanced human capital of either spouse, attributable to education or labor force participation during marriage, generates income after divorce.

To implement this model and to guard against its gender-biased application, I propose bright-line legislation that presumptively establishes (1) a simple mathematical model for calculating enhanced earnings, and (2) a sliding scale that bases the buyout price on the length of the marriage. This model will usually require a husband who earns higher wages to pay maintenance to a wife whose primary caretaking responsibilities have precluded or limited her career choice and advancement.

\section{The Problem}

The home is not an equal-opportunity employer. Even though there is "no 'nurturing' hormone produced along with mother's milk [and] no 'nurturing' gene located in the extra $\mathrm{X}$ chromosome," $" 10$ homemaking is women's work. ${ }^{11}$

Though underpaid, homemaking is not necessarily a useless or unsatisfying occupation. Homemaking is family-specific caretaking that provides a supportive, connected, non-distracting environ-

10 Stark, 38 UCLA L Rev at 1498 (cited in note 4).

11 See note 3. A large proportion of married women who work outside the home assume primary caretaking responsibilities. Bureau of the Census, United States Dept of Commerce, Women in the American Economy, Series P-23, No 146 at 7 (1986). The Bureau reported that "[m] any [wage-earning women] choose work that will fit around . . . their family responsibilities, a complication and impediment to occupational advancement not faced by most men." Id. Professor Deborah Rhode has reported that women remain responsible for approximately $70 \%$ of the housework and working wives spend twice as much time on homemaking tasks as working husbands. Deborah L. Rhode, Justice and Gender: Sex Discrimination and the Law 174 (Harvard, 1989) (citing representative studies). Only one husband in twenty makes the bed in which he sleeps. Id. Susan Faludi suggests that the only major change in the last fifteen years is that now middle class men think they do more around the house. Susan Faludi, Backlash: The Undeclared War Against American Women xiv (Doubleday, 1991) (citing a national poll reporting that the ranks of women saying their husbands share in child care shrunk to $31 \%$ in 1987 from $40 \%$ three years earlier). Over $50 \%$ of wage-earning women have reported dropping out of the labor force for family reasons, as compared to $1 \%$ of wage-earning men. Id. See generally Arlie Hochschild and Anne Machung, The Second Shift: Working Parents and the Revolution at Home (Viking, 1989). As a practical matter, one need only tune in to daytime television commercials to see who cleans the bathrooms. 
ment that nurtures family members, including the caretaker, ${ }^{12}$ and encourages maximization of a wage-earner's human capital. Caretaking, however, takes time. As a consequence, these responsibilities often limit a caretaker's career choice and advancement, thus perpetuating the sexual division of labor in the marketplace.

The reality that homemaking is both gender-specific and career-costly clashes with the rhetoric of equality underpinning nofault divorce laws, which supposes that if spouses receive equal treatment and a clean break on divorce they will begin new lives on an equal footing. ${ }^{13}$ This clash between reality and rhetoric has produced an American tragedy in the forum of divorce, where homemakers repeatedly face the financial slaughter of equal treatment without equal opportunity. To understand the roots of this tragedy, and to avoid a blame-the-victim perspective, one must first examine the traditional role of women under the sex/gender system.

\section{A. The Role-Kinder, Küche, Kirche $e^{14}$}

In American culture, women have long occupied the private sphere of home and family, while men have occupied the public sphere of the marketplace. ${ }^{15}$ According to the traditional stereotype, a woman's primary role is to care for home and family; a "real woman" would never forsake this role for a career. ${ }^{16}$ The fact that most women today, even if they are full-time wage earners, continue to assume primary caretaking responsibilities, evidences

12 Recent studies have suggested, however, that homemaking may disproportionately benefit family members. See Faludi, Backlash at 37 (cited in note 11) (reporting that married women run a higher risk than single women of developing mental and physical ailments, while husbands of homemakers have less psychological distress and higher self-esteem than husbands of working women).

${ }^{13}$ For a general discussion of the clash between equality rhetoric and the economics of divorce, see Martha Albertson Fineman, The Illusion of Equality: The Rhetoric and Reality of Divorce Reform (Chicago, 1991).

"Literally, "children, kitchen, church." This German phrase suggests that women should be confined to their biological role.

${ }^{25}$ For an infamous judicial comment on the public/private sphere dichotomy, see Bradwell v Illinois, 83 US (16 Wall) 130, 141-42 (1872) (Bradley concurring) (a married woman has no right to practice law because "the civil law, as well as nature herself, has always recognized a wide difference in the respective spheres and destinies of man and woman .... [T]he domestic sphere ... properly belongs to the domain and functions of womanhood"). For a discussion of these separate spheres in legal thought, see Rhode, Justice and Gender at 38-50 (cited in note 11).

16 Anthropologist Margaret Mead suggested that a female has two choices: either she proclaims herself "a woman, and therefore less an achieving individual, or an achieving individual and therefore less a woman." William H. Chafe, Women and Equality 15 (Oxford, 1977). 
the tenacity of this stereotype. Its essence, however, must be explored by looking to a time when it was more openly expressed; for instance, the $1950 \mathrm{s.}^{17}$

The view that homemaking is properly women's work was trumpeted in startlingly frank fashion in the 1950s. A woman's "central function," observed one sociologist of the day, "remains that of creating a life style for herself and for the home in which she is life creator and life sustainer."18 A homemaker, chimed the popular press, is a "wondrous creature [who] marries younger than ever, bears more babies and looks and acts far more feminine than the 'emancipated' girl of the 1920's or even '30's. Steelworker's wife and Junior Leaguer alike do their own housework . . . . Today, if she makes an old-fashioned choice and lovingly tends a garden and a bumper crop of children, she rates louder hosannas than ever before." 18 Such housewives were openly applauded as "feminine, women with truly feminine attitudes, admired by men for their miraculous, God-given, sensationally unique ability to wear skirts, with all the implications of that fact."20

The marketplace duplicated this view of the proper role of women, exhibiting an "almost universal opposition to employment of middle-class married women." ${ }^{21}$ Most married women did not work outside their homes. ${ }^{22}$ Those who entered the labor force did so "as a way of filling a hope chest or buying a new home freezer [while] gracefully conced[ing] the top jobs to men."23 Such women took jobs not "out of a desire to compete with men but rather to help the family - a traditional role." ${ }^{24}$ Not surprisingly, the majority of wage-earning women were segregated in low-paying jobs. ${ }^{25}$

17 Susan Faludi has identified several periods in American history when the homemaking virtues were openly trumpeted as part of a backlash against female independence. See Faludi, Backlash at 48 (cited in note 11).

${ }_{18}$ Max Lerner, America as a Civilization 611 (Simon and Schuster, 1957).

19 Betty Friedan, The Feminine Mystique 59 (Norton, 1963), quoting from Look magazine (Oct 16, 1956).

${ }^{20}$ Id, quoting from Life magazine, (Christmas 1956).

${ }^{21}$ Chafe, Women and Equality at 32 (cited in note 16). Professor Chafe explains that being able to provide for a wife at home signified middle class status. A wife's employment cast doubt on her husband's ability to provide for his family. Id.

${ }_{22}$ Professor Chafe reported that in 1940 , only $15 \%$ of all married women were in the labor force. By the end of the 1960 s, this number had reached $45 \%$. Id at 95 .

${ }^{23}$ Friedan, The Feminine Mystique at 59 (cited in note 19), quoting from Look magazine (Oct 16, 1956).

24 Chafe, Women and Equality at 95 (cited in note 16).

${ }^{2 s}$ In 1950 , female wages were $53 \%$ of male wages. Alice Kessler-Harris, Out to Work $381 \mathrm{n} 26$ (Oxford, 1982). Recently, wages of white women have been reported to be $63 \%$ of 
Women who, by force of spirit, resisted the cultural norm and pursued a career rather than a home freezer were generally viewed as "neurotic, unfeminine, unhappy women." ${ }^{26}$ As one popular magazine explained, "Few women would want to thumb their noses at husbands, children and community and go off on their own. Those who do may be talented individuals, but they rarely are successful women."27 In the words of a New York Times editorial, while some housewives "admit to being deeply frustrated at times by the lack of privacy, the physical burden, the routine of family life, the confinement of it, [ ] none would give up her home and family if she had the choice to make again."28 "Real" women knew their priorities.

The demise of full-time homemaking as a grandly trumpeted cultural norm should not delude us into thinking that it never held that status. Many women in divorce courts today decided to devote their lives to homemaking when that role was the only "proper" one for a married woman. Judgment by the forgetful is a dangerous process indeed.

Nor should the lack of open advocacy of the homemaking virtues lure us into thinking that such views are merely remnants of the past. Caretaking is still largely a female role. While many married women today work outside their homes, approximately sixteen million stay out of the labor force because they are "keeping house." ${ }_{28}$ Moreover, most women who work in the marketplace continue to assume primary caretaking responsibilities that limit their occupational choice and advancement. In this respect, many contemporary wives do not differ much from the wives of the 1950s who openly worked for "pin money" and whose priorities were more widely applauded..$^{30}$

white men's wages. Natl Committee on Pay Equity, Pay Equity: An Issue of Race, Ethnicity and Sex 1 (1987), citing US Census Bureau statistics for 1985.

${ }^{26}$ Friedan, The Feminine Mystique at 16 (cited in note 19). See also Chafe, Women and Equality at 94 (cited in note 16). One psychiatrist wrote that any mother who worked was "stimulated by neurotic competition." Id.

${ }^{27}$ Friedan, The Feminine Mystique at 25 (cited in note 19), quoting from Redbaok magazine.

${ }^{28}$ Id, quoting from The New York Times.

29 See notes 3 and 11.

so Indeed, in her 1981 account of the effects of the "Cinderella Complex" on women's employment, Colette Dowling observed:

This need for, and attachment to, "the other" inhibits in all kinds of ways women's capacity to work productively - to be original, zestful, and committed. The myth that our salvation lies in attachment carries with it the hidden corollary that we will not be required to work forever. When suddenly something happens that makes working a 
In at least one respect, however, the position of contemporary wives differs dramatically from the position of wives of the 1950s. Implicit in the cultural message of the 1950s that a woman's proper role is to care for home and family was the predicate that her home and family would be there for her. Divorce was rare, ${ }^{31}$ and the conventional wisdom was that if a woman divorced, her husband would continue to support her through alimony payments. ${ }^{32}$ Restricting a husband's access to divorce insulated the homemaker against the depreciation in marketable human capital that ordinarily accompanies homemaking. No-fault divorce, however, removed this insulation.

\section{B. The "Liberation"-"Equality" for the Homemaker}

In the 1960s and 1970s, traditional reverence for marriage and the family began to decline. Although the cultural message of the 1950 s continued to channel women into homemaking, the virtues of that role were no longer so openly trumpeted. The new cultural

necessity, many become inflamed with a fierce inner rage. To have to work is a sign, somehow, that they have failed as women.

Collette Dowling, The Cinderella Complex 55 (Summit, 1981).

31 Except for a brief period after World War II, divorce increased only gradually from 1860 to the early 1960s. See Weitzman, Divorce Revolution at xvii (cited in note 6). See also Mary E. O'Connell, Alimony After No-Fault: A Practice in Search of a Theory, 23 New England L Rev 437, 478 \& n 236 (1988) (noting a steadily increasing divorce rate from 1860 to 1946 , when it peaked at three times the 1933 rate).

Between 1950 and 1964, the divorce rate remained at between 8.9 and 10.3 per 1,000 women age 15 years and older. By 1970, this rate had increased to 14.9 , and by 1987 it had risen to 20.8. United States Department of Health and Human Services, 3 Vital Statistics of the United States: Marriage and Divorce 2-5, Table 2-1 (1991).

${ }^{32}$ See generally, Homer H. Clark, Jr., 1 The Law of Domestic Relations in the United States 220-21 (West, 2d ed 1987). See also Note, Property Division and Alimony Awards: $A$ Survey of Statutory Limitations on Judicial Discretion, 50 Fordham L Rev 415, 415 (1981). An early example of this assumption in judicial thinking appears in Van Atta $v$ Van Atta, 6 Alaska 266, 267 (D Alaska Terr 1920) ("When a husband brings a suit for divorce, the granting of alimony to the wife is almost a matter of course, for the presumption of the law is that she has no separate means, as the husband usually holds the purse strings.").

Actually, recent evidence suggests that alimony has never been awarded to more than a small proportion of divorcing women. In 1990, the Bureau of the Census reported that only $16.8 \%$ of the 19.3 million ever-divorced and currently separated women (as of 1987) were entitled to receive alimony under the divorce decree. Bureau of the Census, Current Population Reports-Child Support and Alimony: 1987, Series P-23, No 167 at 11 (1990). See generally Ira Ellman, Paul Kurtz, and Katharine Bartlett, Family Law: Cases, Text, Problems 264-65 (Michie, 2d ed 1991). Although the 1990 Census Report included no calculation of the mean amount of alimony received by women in 1987, an earlier study indicated that the mean amount of alimony received by women in 1985 was $\$ 3,730$. Bureau of the Census, Current Population Reports-Child Support and Alimony: 1985, Series P-23, No 152 at 6 (1989). 
watchword was individual fulfillment-"doing your thing."33 This focus on self rather than family paralleled the emerging women's movement, ${ }^{34}$ the increasing number of women working outside the home, ${ }^{36}$ and the declining birth rate. ${ }^{36}$ Most significantly for the homemaker, this new individualism sparked questions about the legitimacy of fault-based divorce laws, which had been increasingly viewed as "annoying anachronisms" since World War II. ${ }^{37}$ In the period between the World Wars, such objections influenced courts to relax the statutory prerequisites to divorce, such as adultery, cruelty, or desertion, and to allow "the flimsiest fabrications to masquerade as evidence of fault." 38

By 1969, dissatisfaction with state restrictions on divorce had led California to enact a statute allowing divorce without a showing of fault. ${ }^{39}$ In 1970, the National Conference of Commissioners on Uniform State Laws boldly approved a Uniform Marriage and Divorce Act ("UMDA"), which authorized the dissolution of any "irretrievably broken" marriage without regard to marital fault.40 The states quickly followed suit. ${ }^{41}$ The heart of the no-fault re-

${ }^{33}$ Chafe, Women and Equality at 167 (cited in note 16). See also O'Connell, 23 New England L Rev at 492 (cited in note 31) (individualistic values triumphed with the passage of no-fault legislation).

${ }^{34}$ The women's movement has been characterized as both a source and a symptom of the emphasis on individualism. Chafe, Women and Equality at 167 (cited in note 16).

ss Id at 121. See note 22. The Civil Rights Act of 1964 prohibited discrimination in employment on the basis of sex. 42 USC $\$ \$ 2000$ e et seq (1988). See also Nancy Barrett, Women and the Economy, in Sara E. Rix, ed, The American Woman 1987-88: A Report in Depth 100 (Norton, 1987) (reporting that the number of women working for pay or looking for paid work has increased by 28 million in the past 25 years).

so Chafe, Women and Equality at 120 (cited in note 16). In 1957, the birth rate peaked at 27.2 children per thousand persons; by 1967 , it had declined to 17.9 , the lowest rate since the Depression. Id.

${ }^{37}$ O'Connell, 23 New England L Rev at 478 (cited in note 31). For a criticism of this focus on self, see Mary Ann Glendon, Abortion and Divorce in Western Law 108-11 (Harvard, 1988).

ss O'Connell, 23 New England L Rev at 479 (cited in note 31). See also Max Rheinstein, Marriage Stability, Divorce and the Law 101-04 (Chicago, 1972); Silva v Silva, 28 Conn Supp 336, 260 A2d 408, 409 (1969).

39 Cal Civ Code $\S 4508$ (West 1983).

to See Uniform Marriage and Divorce Act ("UMDA") §§ 302, 305, 9A ULA 181, 211 (West 1987).

4See Doris Jonas Freed and Timothy B. Walker, Family Law in the Fifty States: An Overview, 18 Family L Q 369, 379-82 (1985). Within five years after California enacted its no-fault statute, most states adopted at least one no-fault ground. Franklin E. Zimring, Foreword, in Steven D. Sugarman and Herma Hill Kay, eds, Divorce Reform at the Crossroads vii (Yale, 1990) ("Divorce Reform"). In the 15 years following approval of the UMDA, every state except South Dakota amended its divorce statutes to allow divorce because of a breakdown of the marriage. Freed and Walker, 18 Family L Q at 379. In 1985, South Dakota added a no-fault provision to its list of fault-based grounds. Act of March 12, 1985, ch 207 § 
forms embodies the partnership notion that marriage is an association of individuals ${ }^{42}$ who may dissolve their relationship at will, compel the liquidation and distribution of their property, and upon winding up their affairs, leave the relationship with no further obligations to one another. This egalitarian scheme initially held great appeal both for proponents of easy access to divorce and for women's rights advocates whose equality rhetoric disavowed the need for male financial support. ${ }^{43}$

Not surprisingly, as divorce became easier to obtain, the number of divorces skyrocketed..$^{44}$ Less expectedly, the no-fault reforms unmasked the reality that homemakers are "just a man away from poverty." 45

\section{The Reality-Economic Tragedy}

When a woman whose principal job has been homemaking loses her occupation and her patriarch, she faces a sea-change in both income and status. The term "displaced homemaker" aptly captures the refugee-like position of such a woman who, after assuming primary responsibility for homemaking is physically exiled

1, 1985 SD Laws 392, codified at SD Cod Laws $\$$ 25-4-2, 25-4-17.1 (1992). For a history of the no-fault movement, see generally Herma Hill Kay, Equality and Difference: A Perspective on No-Fault Divorce and Its Aftermath, 56 U Cin L Rev 1, 54 (1987).

42 The notion that a married woman may be a partner marks a radical departure from the traditional common law view that a married woman lacks capacity to contract, see Bradwell, 83 US at 141, and therefore cannot be a partner. See Little v Hazlett, $197 \mathrm{~Pa} 591$, 47 A 855,858 (1901).

43 Alimony was sometimes viewed as an insult to women and an encumbrance to feminine independence. Weitzman, The Divorce Revolution at 359-60 (cited in note 6). See also Betty Friedan, It Changed My Life 325-26 (Random House, 1976) where she explains:

The women's movement had just begun when the so-called divorce reform law was passed. At that time, we were so concerned with principle-that equality of right and opportunity had to mean equality of responsibility, and therefore alimony was out-that we did not realize the trap we were falling into.

See also Susan Westerberg Prager, Shifting Perspectives on Marital Property Law, in Barrie Thorne and Marilyn Yalom, eds, Rethinking the Family: Some Feminist Questions 111, 123 (Longman, 1982) (noting the failure of California feminists to foresee the economic effects of no-fault divorce on women); and Martha L. Fineman, Implementing Equality: Ideology, Contradiction and Social Change: A Study of Rhetoric and Results in the Regulation of the Consequences of Divorce, 1983 Wis L Rev 789, 853-85 (noting the mistaken belief of Wisconsin reformers that injustice could be avoided by treating marriage as a partnership between equals and equally dividing marital property). But see Fauldi, Backlash at 20 (cited in note 11) (observing that feminists had almost nothing to do with divorce-law reform).

"In the twelve years between 1963 and 1975, the divorce rate increased $100 \%$. In each following year until 1981, the divorce rate surpassed all previous U.S. records. In 1981, there were 1.21 million divorces. Weitzman, The Divorce Revolution at xvii (cited in note 6).

is Status Report (1990) at 60 (cited in note 3). 
from her home. Her exile is not an isolated phenomenon. In its 1989 survey, the Census Bureau counted 15,600,000 displaced homemakers, an increase of twelve percent over 1980 figures. $^{46}$ The majority of mid-life and younger homemakers were displaced by divorce or separation. ${ }^{47}$

A homemaker displaced through divorce often suffers an immediate and dramatic decline in economic status. Lenore Weitzman's data indicate that in the first year after divorce women and children average a seventy-three percent decline in their standard of living while men enjoy a forty-two percent rise. ${ }^{48}$ Often, displacement plunges a homemaker into poverty. The Displaced Homemakers Network ("DHN") ${ }^{49}$ reports that approximately fifty-seven percent of former homemakers earn poverty or nearpoverty incomes, ${ }^{50}$ a figure that is even higher for women of color. ${ }^{51}$

${ }_{48}$ Bureau of the Census, Current Population Report (1989) ("Population Report 1989"). See also DHSSAA, 29 USCA $§ 2301$ (a)(3) (West Supp 1991) (stating the Congressional finding that "there are approximately 15,600,000 displaced homemakers in the United States, the majority of whom are women not in the labor force, who live in poverty and who require educational, vocational, training and other services to obtain financial independence and economic security"). Data on "displaced homemakers" can vary widely depending on how the term is defined. Though the DHSSA refers to the Census Bureau tally of 15.6 million displaced homemakers, it is not clear that the Census Bureau used the DHSSA definition, quoted in note 7. The Displaced Homemakers Network ("DHN") defines "displaced homemaker" very broadly; the data referred to in notes $47-52$ is based on this broad definition.

A displaced homemaker is a woman whose principal job has been homemaking and who has lost her main source of income because of divorce, separation, widowhood, disability, or long-term unemployment of a spouse, or loss of eligibility for public assistance. If she is employed at all, she works part-time or part of the year.

Status Report (1990) at 1 (cited in note 3).

${ }^{47}$ Approximately $55 \%$ of displaced homemakers ages $35-64$ and $87 \%$ of those under 35 years old are divorced or separated. Id at 1.

48 Weitzman, The Divorce Revolution at 323 (cited in note 6). Those who criticize Weitzman's figures often report a smaller post-divorce disparity in income. See, for example, Faludi, Backlash at 19-25 (cited in note 11) (citing a study reporting a 30 percent temporary decline in women's living standards and a 10-15 percent improvement for men).

10 The DHN is a private, not-for-profit, national grass roots organization established in 1979. Jill Miller, Working Paper on Displaced Homemakers in the Employment and Training System 3 (1988) (on file with U Chi L Rev). The stated purpose of the DHN is "to increase displaced homemakers' options for economic self-sufficiency, to provide information about the public policy issues which affect displaced homemakers, to provide technical assistance resources for service providers and to help ... develop programs that work for displaced homemakers." Id, outside back cover.

so The DHN bases this calculation on the Census Bureau's definition of poverty, which varies by household size, age of householder, and number of children and adults. See Status Report (1990) at 20 (cited in note 3). In the 1989 survey, the poverty threshold for a household of three was $\$ 9,435$. Id. A near poverty income, using 1989 measures, would be $\$ 14,125$. Id. 
Compounding her difficulties is the likelihood that a displaced homemaker has lost any home she owned with her husband. ${ }^{\mathbf{2}}$

The typical homemaker, who receives little or no property or maintenance upon divorce, ${ }^{53}$ has at least three options for economic survival: she can find a new husband, commence or expand her participation in the labor force, or rely on public or private assistance. Each of these options is beset with roadblocks.

The option most consistent with the sex/gender system is to find a new husband. While a new husband may well provide immediate financial relief, this option risks perpetuating a homemaker's economic vulnerability, thus exposing her to the possibility that at some later date, perhaps when marriage is less likely because of the presence of children or advancing age, she will again lose her male buffer. If the homemaker is older, her decision to wait for a new male provider may be especially risky: recent studies suggest that as a woman ages, her opportunities for remarriage decline dramatically and much more decidedly than those of a man. ${ }^{54}$ Indeed, an older woman's decision to wait for a male rescuer suggests the irrationality as well as the tenacity of the "Cinderella Complex" under the sex/gender system.

51 Id at 21 . While $27.8 \%$ of White displaced homemakers are poor, $61 \%$ of Black displaced homemakers and $62.3 \%$ of Hispanic displaced homemakers are poor. Id. While $23 \%$ of White displaced homemakers are near-poor, only $20.1 \%$ of Black and $15.7 \%$ of Hispanic displaced homemakers are near-poor. Id. Overall, the DHN concludes that approximately one-half of White displaced homemakers and three-fourths of Black and Hispanic displaced homemakers are living in or near poverty. Id.

s2 The DHN, relying on 1989 Census Bureau figures, reports that while $56.1 \%$ of all displaced homemakers own a home, only $34.6 \%$ of divorced or separated women are homeowners. Status Report (1990) at 29-30 (cited in note 3). From this data, the DHN surmises that "more than half of women who . . . divorce or separat[e] lose home ownership and become renters." Id at 30 (emphasis in original). For a discussion of the disposition of the marital home on divorce, see generally Comment, The Marital Home: Equal or Equitable Distribution?, 50 U Chi L Rev 1089 (1983).

ss For a fuller discussion of property and maintenance determinations under no-fault, see Section II.

84 See Lenore J. Weitzman, The Economics of Divorce: Social and Economic Consequences of Property, Alimony and Child Support Awards, 28 UCLA L Rev 1181, 1228-29 (1981). See also Ira Mark Eliman, The Theory of Alimony, $77 \mathrm{Cal} \mathrm{L}$ Rev 3, 43-44 (1989). This decline in marriageability through age is much less severe for men. Id. To state the extreme, it is easier for the tycoon to find another trophy wife than for the trophy wife to find another tycoon. But see Faludi, Backlash at 9-19 (cited in note 11) (debunking the popular myth that never-married, college-educated women over thirty have a slim chance of marriage.)

ss See generally Dowling, The Cinderella Complex (cited in note 30). Dowling describes the "Cinderella Complex" as "a network of largely repressed attitudes and fears that keeps women in a kind of half-light, retreating from the full use of their minds and creativity. Like Cinderella, women today are still waiting for something external to transform their lives." Id at 31 . 
A more reasonable choice for a displaced homemaker might be to commence or expand participation in the marketplace. The homemaker who chooses this option, however, may be disillusioned to discover that the marketplace largely mirrors the sexual division of labor in the home. Despite recent expansion of employment opportunities, women continue to earn less than men and to find employment in the secondary job market where opportunities for advancement are limited. ${ }^{56}$.

If she has been out of the labor force for any period, the homemaker will probably never reach the income level she would have enjoyed through uninterrupted wage-earning. Mincer and Polachek found that women experience a 1.5 percent loss in earning capacity for each year out of the labor force. ${ }^{57}$ Employers often view the former full-time homemaker as an unattractive candidate for employment, due both to her lack of recent, full-time job experience, and her limited or dated education..$^{58}$ Such a homemaker will be hard-pressed to convince many prospective employers that her caretaking skills have marketable value. ${ }^{\text {69 }}$

se In 1969, women earned 63 cents to a man's \$1.00. Mary Corcoran, Greg J. Duncan, and Martha S. Hill, The Economic Fortunes of Women and Children: Lessons from the Panel Study of Income Dynamics, 10 Signs 232, 234 (1984). More recent data suggests continuing disparities. See Rhode, Justice and Gender at 161-75 (cited in note 11) (observing that after 2,500 years the biblical valuation of women at 30 shekels and men at 50 has remained fundamentally unchanged). Professor Rhode cites data from the late 1980s indicating that among full-time workers, the average female college graduate still earns significantly less than the average male with a high school diploma. Id at 163 . Such disparities stem at least partly from the channeling of women into the secondary job market, which offers low wages and little chance for advancement. These traditionally female jobs include child care worker, clerical worker, waitress, and retail employee. See Status Report (1990) at 59 (cited in note 3). Susan Faludi reports that nearly $80 \%$ of working women are clustered in traditional "female" jobs-as "secretaries, administrative 'support' workers and sales clerks." Backlash at xiii (cited in note 11). See generally Julie A. Matthaei, An Economic History of Women in America: Women's Work, The Sexual Division of Labor, and the Development of Capitalism (Schocken, 1982).

57 Jacob Mincer and Solomon Polachek, Family Investments in Human Capital: Earnings of Women, in Theodore W. Schultz, ed, Economics of the Family: Marriage, Children, and Human Capital 397, 415 (Chicago, 1974).

ss The DHN reports that $34 \%$ of displaced homemakers under age 35 and $39 \%$ of displaced homemakers between ages 35 and 45 lacked a high school diploma. See Status $R e-$ port (1990) at 19 (cited in note 3). If an older homemaker has a college degree, it is likely to be dated-a factor that will do little to improve her marketability, especially if she seeks professional employment in a field in which she never worked. Consider, for example, the plight of a nurse or medical technologist who seeks to market for the first time a degree she earned in that field 20 years ago.

so Dean Yarbrough suggests that long-term homemakers could increase their employment opportunities by persuasively documenting the experience they gained through homemaking, and she encourages potential employers to consider seriously these credentials. Yarbrough, $49 \mathrm{~L}$ \& Contemp Probs at 120, 124-25 (cited in note 3). But see Rae André, 
If the homemaker is younger, her struggle to become self-supporting may be frustrated by the same factor that initially limited or precluded her participation in the labor force-she is likely to be custodian of any children of the marriage and thus must continue to juggle the demands of home and family. ${ }^{80}$ If the homemaker is older, the insidious reality of age discrimination compounds her struggle. She may be considered too old for training programs, both because she may have fewer years in which to apply that training and because she is perceived as inflexible, lacking stamina, and given to health problems. ${ }^{61}$ Dean Marilyn Yarbrough has observed that the Age Discrimination in Employment Act ("ADEA") of $1967^{62}$ has done little to combat this discrimination against displaced homemakers. ${ }^{63}$

A displaced homemaker who is unsuccessful in her struggle for economic self-sufficiency may turn to private or public organizations for help. This option is bound to be a disappointment. The DHN is the principal private source of support for former homemakers. This grass roots organization attempts to provide career assessment and counseling, skills training, pre-employment preparation, and job placement services. ${ }^{64}$ Inadequate funding, however,

Homemakers, the Forgotten Workers 202 (Chicago, 1981) (warning that advising a woman that her homemaking skills have market value may raise false hopes and damage her selfesteem when she tries to sell her skills to an employer).

${ }^{\text {Bo }}$ Ninety percent of the children in single-parent families live with their mothers. Elizabeth A. Mulroy, Introduction, in Elizabeth A. Mulroy, ed, Women as Single Parents: Confronting Institutional Barriers in the Courts, The Workplace, and the Housing Market 3 (Auburn House, 1988).

61 See Yarbrough, $49 \mathrm{~L} \&$ Contemp Probs at 114 (cited in note 3).

${ }^{62} 29$ USC \$§ 621-34 (1988 and Supp 1990). The ADEA generally prohibits discrimination on the basis of age against non-federal employees between ages 40 and 70 . Id at $\S \S$ 631(a), 633(a).

${ }^{63}$ See Yarbrough, $49 \mathrm{~L}$ \& Contemp Probs at 109 (cited in note 3). Dean Yarbrough notes that the legislative history of the ADEA suggests a limited focus: the family breadwinner who finds himself unemployed and is experiencing difficulty in finding new employment because of his age. Id. Indeed, Dean Yarbrough observes that most actions brought under the ADEA have involved white males. Id at 111.

Dean Yarbrough explains that the ADEA's ability to curtail discrimination against displaced homemakers has been hampered by a provision in the Act allowing an employer to defend a claim of age discrimination by establishing that its action was "based on reasonable factors other than age." See id. Such factors may include an applicant's lack of recent full-time job experience-a common attribute of a newly displaced homemaker.

B4 DHN Program and Policy Statement, reprinted in National Displaced Homemakers Network, A Handbook on State Displaced Homemaker Legislation: 1990-1991 Update 47 (1991) (on file with U Chi L Rev) ("Handbook"). 
frustrates the ability of most programs to offer meaningful services. ${ }^{68}$

State and federal programs that might aid displaced homemakers also are generally ineffective. ${ }^{66}$ While at least twenty-six states have legislation authorizing special programs for displaced homemakers, ${ }^{67}$ these programs receive minimal funding and are especially vulnerable to cutbacks during times of economic difficulty. ${ }^{68}$

Federal programs have fared no better for the displaced homemaker. ${ }^{69}$ A key example is the Job Training Partnership Act ("JTPA") of $1982,{ }^{70}$ which seeks to "prepare ... unskilled adults for entry into the labor force and to afford job training to those economically disadvantaged individuals . . . facing serious barriers to employment . ..."1 Despite its promising ambitions, JTPA has disappointed displaced homemakers, who tend to be viewed as poor investments and thus have difficulty obtaining JTPA funds. ${ }^{72}$

65. Miller, Working Paper at 4 (cited in note 49). The DHN receives its funding through government grants and private contributions. Most of the 1,000 programs the DHN oversees are operated by a staff of only one to two full-time and one to two part-time employees, and most operate on a budget of less than $\$ 40,000$ per year. Id.

os See the Congressional finding in DHSSAA, 29 USCA § 2301(a)(4): "Federal, state and local programs addressing the training and employment needs of displaced homemakers have been fragmented and insufficient to serve displaced homemakers effectively."

${ }^{67}$ Handbook at 7 (cited in note 64).

${ }^{68}$ The majority of states with displaced homemaker legislation appropriate between $\$ 200,000$ and $\$ 950,000$ per year to the programs collectively. Id at 7 . Fourteen states distribute less than $\$ 50,000$ annually to individual programs. Six distribute $\$ 60,000$ to $\$ 80,000$ per program, and six distribute over $\$ 100,000$ per program. Id at 11 . Despite inflation and rising costs, most states have failed to adjust annual funding for these programs. Id. During the three years prior to 1991, at least four states cut their funded programs. Id.

60 See DHSSAA, 29 USCA § 2301(a)(4) (stating the Congressional finding that federal as well as state programs have been ineffective in serving displaced homemakers).

${ }^{70} 29$ USC $\S 1501$ et seq (1988). Federal vocational education acts, such as the Perkins Act of 1984, have also provided only minimal aid to displaced homemakers. See 29 USC $\S 2301$ et seq (1991). The Perkins Act was originally designed to improve vocational programs, to correct patterns of underservice, and increase access to vocational education among populations previously underserved. Carl D. Perkins Vocational Education Act of 1984, Pub L No 88-210 § 2, as amended by Pub L No 98-524 § 1, 98 Stat 2437, revised by Pub L No 101-392, 104 Stat 756. It explicitly requires states to target $8.5 \%$ of their basic state grants for vocational education to single parents and homemakers and to give special attention to "displaced homemakers who ... a are entering or reentering the labor force." 20 USCA at $\S \S 2332,2372$. As with JTPA, however, federal funding has been limited. See Miller, Working Paper at 14 (cited in note 49). The 1990 amendments to the Perkins Act specifically name displaced homemakers as a target population. 29 USCA § 2335.

729 USC § 1501 (1988).

72 Miller, Working Paper at 11 (cited in note 49). Miller, as Executive Director of the DHN, reports that JTPA administrators emphasize the bottom line-securing high placement rates for JTPA trainees. This emphasis encourages "creaming": choosing clients who are most easily and cheaply placed in jobs. By definition, displaced homemakers are not 
Even if a displaced homemaker is selected for JTPA training, she may experience only a marginal improvement in her marketability, because training is delivered along "very traditional lines for each gender." As As one DHN program reported: "Some of the training is for jobs which turn out to be minimum-wage and part-time, such as a recent one in telemarketing and telecommunication-phone solicitation in other words." 4

More recently, Congress responded to the plight of displaced homemakers by enacting the Displaced Homemakers Self-Suffciency Assistance Act ("DHSSAA"). ${ }^{75}$ The DHSSAA allocates funding for state programs that provide career counseling, training, and placement for displaced homemakers. ${ }^{76}$ It authorizes $\$ 35$ million for fiscal year 1991, and such sums as may be necessary thereafter. ${ }^{77}$

While the DHN hails the DHSSAA as "landmark legislation,"78 it is something less than a panacea. A simple calculation reveals that the $\$ 35$ million authorized to "expand the employment and self-sufficiency options of displaced homemakers"79 will provide less than $\$ 3.00$ for each of the 15.6 million displaced homemakers in this country, most of whom live in poverty. ${ }^{80}$ One wonders how much self-sufficiency $\$ 3.00$ can buy.

Divorce may thus leave a displaced homemaker alone, with limited employment options, and without meaningful assistance. While no-fault did not create the sex/gender system that is largely responsible for this situation, no-fault exacerbates the effects of

among this group. Id. Even if a displaced homemaker is selected for JTPA training, she probably will not receive the financial support necessary to sustain her during her training. Id. Moreover, the DHN complains that available funds can serve only 4 percent of the eligible population. Id.

${ }^{73}$ Status Report (1990) at 62 (cited in note 3). One DHN program reported that it referred very few clients for JTPA training because even with the training they could earn little more than AFDC and in one case a woman was worse off than being on welfare. Miller, Working Paper at 11 (cited in note 49).

34 Id.

7829 USCA $\S \S 2301$ et seq (West Supp 1991).

${ }^{38}$ Id at $\$ 2309$.

77 Id at $\S 2314$. States must compete for DHSSAA funds in any year in which appropriations are under $\$ 25$ million; in years in which the annual appropriation reaches $\$ 25$ million or more, financial assistance is allocated to every state in proportion to the adult population of that state. Id at $\S \S 2303,2306$.

${ }^{78}$ Displaced Homemakers Network, Guide to the Displaced Homemakers Self-Suffciency Act 5 (1991).

${ }^{7}$ DHSSAA, 29 USCA \& 2301(b).

${ }^{80}$ Id at $\S 2301(\mathrm{a})(3)$. 
that system by removing the insulation of marriage from increasing numbers of women with little thought to economic consequence.

\section{The Mistakes of No-Fault}

The no-fault reformers devoted much effort to selling the concept of no-fault, but gave little consideration to its economic consequences. ${ }^{81}$ Rather incidentally, the no-fault campaign inspired two. significant changes in the rules affecting the economics of divorce. First, no-fault reforms encourage final settlement of the parties' mutual obligations through a one-time division of marital property, ${ }^{82}$ thus effecting a clean break. ${ }^{83}$ Second, no-fault reforms presume that any maintenance awarded should be temporary and for the purpose of rehabilitating a needy spouse. ${ }^{84}$ While each change often can be traced to specific language in no-fault statutes, the draconian application of these general rules has come at the hands of gender-biased courts vested with very broad discretionary powers. As applied, no-fault reforms in both the division of property and the award of maintenance have made divorce a financial catastrophe for homemakers.

\section{A. Property Distribution}

No-fault presumes that a one-time division of traditional property on divorce will equitably settle the parties' rights and responsibilities. This presumption has proved to be wishful thinking. The typical insubstantial amount of tangible marital assets, together with the discretionary nature of the division of those assets, often make the division of property both insignificant and unpredictable.

82 O'Connell, 23 New England L Rev at 493 (cited in note 31), citing Levy, Uniform Marriage and Divorce Legislation: A Preliminary Analysis 138-39 (papers prepared for the Special Committee on Divorce of the National Conference of Commissioners on Uniform State Laws).

${ }^{82}$ See UMDA, § 308 Official Comment, 9A ULA 348 (West 1987):

The dual intention of this section and Section 307 is to encourage the court to provide for the financial needs of the spouses by property disposition rather than by an award of maintenance. Only if the available property is insufficient for the purpose and if the spouse who seeks maintenance is unable to secure employment appropriate to his skills and interests or is occupied with child care may an award of maintenance be ordered.

${ }^{83}$ For a discussion of the partnership roots of this clean break, see notes 188-94 and accompanying text.

Bs See text accompanying note 159 . 
1. Minimal assets.

When marital assets are substantial, a court might ease the financial straits of a homemaker with low income potential by awarding her a significant amount of marital property. Most marital estates, however, are too small to make this option feasible. ${ }^{85}$ It is not unusual for lower and middle-class couples to live from paycheck to paycheck and to own few if any significant assets. In the worst case, in which a couple's debts exceeds its assets, the homemaker who receives most or even all of the marital property may still receive little or nothing. ${ }^{86}$ Often, a couple's only important asset is equity in a marital residence. ${ }^{87}$ When the parties lack other assets, this equity can be divided only if the home is sold; ${ }^{88}$ in fact, sale of the home is frequently ordered. ${ }^{89} \mathrm{~A}$ homemaker may

ss Professor Weitzman's research, for example, indicates that half of the divorcing couples in Los Angeles county in 1978 had less than $\$ 20,000$ in assets. Weitzman, The $D i$ vorce Revolution at 56-57 (cited in note 6). See also Ilene E. Shapiro and Barry P. Schatz, Has the Illinois Equitable Distribution Statute Advanced the Cause of the Homemaker?, Ill Bar J 492, 500 (June 1986) ("most estates are too small to support anyone").

s6 Several legal commentators have advocated an unequal division of property. Professor Martha Fineman, for example, argues that an equal division of property is inequitable since "need cannot be alleviated by equal divisions so long as other factors between men and women remain unequal." Fineman, The Illusion of Equality at 178 (cited in note 13). What is needed, suggests Professor Fineman, is result-equality rather than rule-equality. Id at 2-6. See also Suzanne Reynolds, The Relationship of Property Division and Alimony: The Division of Property to Address Need, 56 Fordham L Rev 827, 907-16 (1988); Barbara Stark, Burning Down the House: Toward a Theory of More Equitable Distribution, 40 Rutgers L Rev 1173, 1179 (1988) (homemaking wife should presumptively receive more than half of property). It is true that many women will be severely disadvantaged if they receive an equal division of marital property and nothing more. It is my position, however, that such women should receive something more: maintenance as buyout.

87 From data collected in 1979, Professor Mary Ann Glendon reported that approximately $65 \%$ of families owned a house, and that nearly $41 \%$ lived in mortgaged homes with an average equity of $\$ 26,000$. Mary Ann Glendon, The New Family and the New Property 94 (Butterworths, 1981). More recently, Professor Marsha Garrison reported a similar incidence of home ownership in New York (64\% in 1978,68\% in 1984) and much greater equity ( $\$ 61,665$ in 1978 and $\$ 83,968$ in 1984). Marsha Garrison, The Economics of Divorce, Changing Rules, Changing Results, in Divorce Reform at 75, 82, 88 (cited in note 41). Professor Garrison's equity figures are based on a survey of 900 contested divorces. Id.

sa A homemaker might avoid sale, of course, if there are other assets to offset against the home equity or if she has separate property sufficient to enable her to buy out her husband's interest.

89 The DHN reports that roughly one-half of the displaced homemakers who are divorced or separated lose home ownership and become renters. Status Report (1990) at 30 (cited in note 3) (extrapolating from data contained in the Census Bureau's 1989 Current Population Survey). Weitzman reports erosion in California of the long tradition of awarding the family home to the wife, especially if she has custody of children. In 1968, wives in Los Angeles and San Francisco were awarded $60 \%$ or more of the marital property, which usually allowed them to keep the family home. With the advent of no-fault in 1970, the wives' share of the property declined and the number of family homes ordered sold upon 
thus leave the marriage with limited income potential, few if any assets, and no home.

Some courts and legislatures concerned by this possibility have attempted to increase the pool of marital assets by expanding the definition of marital property. An expanded definition might include such nontraditional assets as a spouse's pension, goodwill in a business, and a professional degree or license. Increasing the marital pot allows a court to award a low-income wife a larger share of traditional property or a lump-sum payment reflecting her share of nontraditional property.

Some nontraditional assets are more often characterized as marital property than others. Most states, either by statute or judicial decision, have expanded the definition of marital property to include pensions and retirement plans. ${ }^{90}$ Identifying a method of valuation and a proper time for distribution, however, continues to trouble courts.

A recurring issue is whether the pension is to be valued at the time of divorce (the immediate offset method), or "if, as, and when" it is received (the deferred distribution approach). ${ }^{91}$ The choice is often left to the discretion of a trial court. ${ }^{22}$ If a couple lacks other significant assets, a court's decision to value and dis-

divorce skyrocketed. In 1968, courts explicitly ordered sale of the family home in one case in ten; by 1977 this figure had risen to one in three. Weitzman, The Divorce Revolution at 3031 (cited in note 6). Concern for the welfare of children led California in 1988 to enact legislation favoring deferred sale when minor children are in the home. Cal Civ Code $\S$ $4700.10(a)(2)$ (West Supp 1991). For a discussion of this provision, see Herma Hill Kay, Beyond No-Fault; New Directions in Divorce Reform, in Divorce Reform at 6, 21-22 (cited in note 41). See also Marsha Garrison, The Economics of Divorce, in Divorce Reform at 88 (reporting a statistically significant increase between 1978 and 1984 in the number of divorcing husbands who retained the marital home).

90 Freed and Walker, 18 Family L Q at 424-26 (cited in note 41). See generally Note, Pension Awards in Divorce and Bankruptcy, 88 Colum L Rev 194 (1988); and Grace Blumberg, Marital Property Treatment of Pensions, Disability Pay, Workers' Compensation and Other Wage Substitutes: An Insurance, or Replacement, Analysis, 33 UCLA L Rev 1250 (1986). For a discussion of pension benefits in community property states, see Phoebe Carter and John Myers, Division and Distribution of the Community Interest in Defined Benefit Pensions: Schweitzer Reconsidered, 18 NM L Rev 95 (1988).

91 Compare Kilbride v Kilbride, 172 Mich App 421, 432 NW2d 324, 331 (1988); and Shill v Shill, 115 Idaho 115, 765 P2d 140, 145 (1988) (both employing immediate offset method); with Cearley v Cearley, 544 SW2d 661 (Tex 1976); and In re Marriage of Brown, $15 \mathrm{Cal} \mathrm{3d} \mathrm{838,} 126$ Cal Rptr 633, 544 P2d 561, 569-70 (1976) (both employing deferred distribution approach). See also Ind Code Ann § 31-1-11.5-11(b)(4) (West Supp 1992) (authorizing a trial court to distribute pension benefits by "setting aside to either of the parties a percentage of those payments either by assignment or in kind at the time of receipt").

92 See Ind Code Ann § 31-1-11.5-11(b) (directing a trial court to divide property in a "just and reasonable manner" by "ordering the distribution of any [pension] benefits"). See also id at $\S 11(b)(4)$ (apparently addressing the distribution rather than valuation). 
tribute benefits when they are received may leave a homemaker financially strapped until her spouse chooses to retire. Moreover, sharing of pension benefits can provide meaningful relief for a homemaker only when sizable benefits exist.

Generally, the definition of marital property includes goodwill in a business if it was acquired during the marriage and has marketable value. ${ }^{93}$ There are limits, however, to the general willingness of courts to value and divide this goodwill. Recently, a New York court declined to expand goodwill concepts to include celebrity status, concluding that a musician's royalties from his recordings were the only marital asset deriving from his celebrity status. ${ }^{94}$ Moreover, one suspects that not all trial courts seriously consider evidence of goodwill. Weitzman reports, for example, that some California judges actually consider testimony regarding goodwill a farce..$^{95}$

Very few courts have expanded the definition of property to include a spouse's professional degree or license, ${ }^{96}$ although courts

${ }^{93}$ See Herma Hill Kay, Beyond No-Fault: New Directions in Divorce Reform, in Divorce Reform 6, 13-14 (cited in note 41). In 1985, Weitzman reported that Los Angeles judges found goodwill in "the professional practices of an accountant, architect, banker, consultant, dentist, doctor, engineer, insurance agent, lawyer, pharmacist, professor, sales representative, social worker, and in a wide range of small and large businesses including a barber shop, hardware store, restaurant, indoor sign business, and beauty salon chain." Weitzman, The Divorce Revolution at 122 (cited in note 6). The goodwill in these enterprises was valued at between $\$ 100$ and $\$ 720,000$. Id.

More recently, a New Jersey court, in a widely-publicized case, found that Joe Piscopo's "celebrity goodwill" was a marital asset subject to distribution. See Piscopo v Piscopo, 232 NJ Super 559, 557 A2d 1040, 1042-43 (1988).

${ }^{24}$ See Getz v Getz, 15 Family L Rep (BNA) 1254, 1254 (NY Sup Ct 1989). For a discussion of New York's treatment of celebrity status on divorce, see generally Note, "Do You Promise to Love, Honor, and Equitably Divide Your Celebrity Status on Divorce?" A Look at the Development and Application of New York's. Equitable Distribution Statute, 9 Loyola Ent L J 153 (1989). For a discussion not limited to New York, see generally John R. Phillips, Valuing Intangible Celebrity Assets, 12 LA Lawyer 24 (April 1989).

${ }^{85}$ Weitzman cites one California judge, for example, who frankly acknowledged,

To tell you the truth, I think goodwill is a lot of b.s. There's nothing there. And it burns me up to have to sit there for hour after hour listening to b.s. from accountants. They invent the formulas on the spot.... They think they are putting one over because they bring in color charts and graphs .... . Well, I don't buy any of it. Weitzman, The Divorce Revolution at 123 (cited in note 6).

so See Kay, Beyond No-Fault in Divorce Reform at 14 (cited in note 41) ("virtually all the states that have faced the issue to date have resisted the characterization of professional degrees or licenses as property subject to division upon divorce"). For an argument in support of a property classification, by an author who ultimately criticizes it, see Joan $M$. Krauskopf, Recompense for Financing Spouse's Education: Legal Protection for the Marital Investor in Human Capital, 28 Kan L Rev 379 (1980). 
in over half the states have addressed this question. ${ }^{97}$ Cases raising this issue usually involve a recently-acquired advanced degree or license that has not matured into a business or practice and thus has not yet generated any marital property. ${ }^{98}$

The refusal of courts to classify such a degree or license as property reflects a general view that this intangible "is simply an intellectual achievement that may potentially assist in the future acquisition of property. ... [I]t has none of the attributes of property in the usual sense of that term."99 The occasional effort of trial courts to classify such an intangible as property is often reversed on appeal. ${ }^{100}$

The facts of O'Brien v O'Brien, a 1985 New York case, aptly demonstrate the inequity that can result from insistence upon traditional definitions of property. ${ }^{101}$ Eighteen months after their wedding, the O'Briens moved to Mexico so that Mr. O'Brien could attend medical school. During most of the couple's nine-year marriage, Ms. O'Brien worked as a teacher to finance her husband's medical education. The same year he received his medical degree, Mr. O'Brien commenced divorce proceedings. Since Ms. O'Brien appeared ineligible for maintenance under New York law, ${ }^{102}$ and

97 Virginia S. Renick, Spousal Contribution to a Professional Degree Upon Divorce: The State of the Law, in Ronald L. Brown, ed, Valuing Professional Practices and Licenses; A Guide for the Matrimonial Practitioner 27, 29 (Prentice Hall, 1987).

${ }^{88}$ See Stanley L. Goodman, How Dr. O'Brien's Medical License Was Valued, in Brown, Valuing Professional Practices 77, 86 (cited in note 97) (explaining that if Dr. O'Brien's license to practice medicine had matured into a practice, the practice rather than the license would have been valued). Compare John F. Burke, Jr. and Harvey S. Rosen, Valuing Educational Attainment as a Distributable Asset, in Brown, Valuing Professional Practices 61, 71-72 (cited in note 97) (arguing that a practice and license do not necessarily merge and should be separately valued).

op In re Marriage of Graham, 194 Colo 429, 574 P2d 75, 76 (1978). In Graham, the husband attended school for three and one-half of the six years of marriage; the wife contributed $70 \%$ of the income; and there were no tangible marital assets. Id at 76 . While the court refused to classify the husband's degree in business administration as marital property, it suggested that the degree could be considered in the division of property and in any maintenance award. Id at 78.

${ }^{100}$ See, for example, Lynn $v$ Lynn, 49 USLW 2402 (NJ Super 1980), rev'd, 91 NJ 510, 453 A2d 539, 542 (1982); Inman v Inman, 578 SW2d 266, 268 (Ky App 1979), rev'd, 648 SW2d 847, 852 (Ky 1982).

10166 NY2d 576, 498 NYS2d 743, 489 NE2d 712 (1985).

${ }^{102}$ See Goodman, Dr. O'Brien's Medical License at 79 (cited in note 98) (attorney who testified as expert witness for Ms. O'Brien believed maintenance was not available to her). Even in cases where it is available, maintenance may be an inadequate basis for alleviating income disparity in a student/non-student marriage, because maintenance typically terminates upon the remarriage of a receiving spouse- $a$ consequence that seems inconsistent with the investment nature of a non-student's contribution. Courts have noted this problem in various cases involving a non-student spouse. See, for example, Hubbard v Hubbard, 603 
the couple had not yet acquired significant traditional property, ${ }^{103}$ Ms. O'Brien's financial recovery depended on her ability to convince the court to reach beyond traditional definitions of property and award her a share of her husband's professional license. In an extraordinary departure from tradition, the Court of Appeals did just that. Classifying Mr. O'Brien's medical license as marital property, the Court of Appeals affirmed the trial judge's award of forty percent of its present value to Ms. O'Brien. ${ }^{104}$ The court's holding, however, was limited to an interpretation of the legislative intent underlying New York's Equitable Distribution Law, which the court found deliberately exceeded traditional property concepts. ${ }^{105}$ Unfortunately for other wives who finance their husbands' educations, O'Brien continues to be an extraordinary case.

Although few courts classify a professional degree or license as property, many courts perceive some inequity when parties divorce before investments in education have generated traditional marital property. ${ }^{108}$ While practitioners' attempts to urge a property classi-

P2d 747, 752 (Okla 1979). See also Woodworth $v$ Woodworth, 126 Mich App 258, 337 NW2d 332,337 (1983); and O'Brien, 489 NE2d at 717-18.

${ }^{103}$ O'Brien, 489 NE2d at 713.

${ }^{104}$ Id at 714 . This percentage amounted to $\$ 188,800$. Id. The value of such a license, reasoned the court, lies in "the enhanced earning capacity it affords the holder." Id at 717. Compare the refusal of a New Jersey court to classify a master's degree in business administration as marital property because its value consisted of "nothing more than the possibility of enhanced earnings." Mahoney, $453 \mathrm{~A} 2 \mathrm{~d}$ at 532.

105489 NE2d at 715. See also Herma Hill Kay, An Appraisal of California's No-Fault Divorce Law, 75 Cal L Rev 291, 313 n 171 (1987). Applying O'Brien, the New York Appellate Division recently included a wife's master's degree within the definition of marital property. See McGowan v McGowan, 535 NYS2d 990, 142 AD2d 355 (1988).

${ }^{108}$ Often, courts attempt to aid a non-student spouse without actually classifying a degree or license as property. One example is Woodworth, 337 NW2d at 332. In Woodworth, the court affirmed division of the value of a husband's law degree while candidly conceding that "whether or not an advanced degree can physically or metaphysically be defined as 'property' is beside the point." Id. The preferred approach, reasoned the court, is to "focus on the most equitable solution to dissolving the marriage and dividing among the respective parties what they have." Id.

Other courts have sought to address a perceived inequity by construing maintenance statutes broadly enough to authorize a lump-sum payment to a non-student spouse. See, for example, In re Marriage of Lundberg, 107 Wis 2d 1, 318 NW2d 918, 923 (1982) (approving maintenance award compensating a wife for her contribution to her husband's medical degree during an eight-year marriage). Such a broad construction of maintenance statutes is not always possible. See text accompanying notes 157-68.

Still other courts have invoked their equity powers to order restitution of the non-student's monetary contributions to avoid unjust enrichment. See Hubbard, 603 P2d at 752; and De LaRosa $v$ De LaRosa, 309 NW2d 755, 758 (Minn 1981). This restitution may be labelled "reimbursement alimony." See Mahoney, 453 A2d at 534, where a New Jersey court defined reimbursement alimony to include household expenses, educational costs, and travel expenses to school. See also Saint Pierre v Saint Pierre, 357 NW2d 250, 262 (SD 1984) 
fication on unmatured degrees or licenses is an understandable effort to alleviate income disparity, one must question the conceptual integrity of efforts to contort these intangibles to fit within traditional definitions of property. ${ }^{107}$

Moreover, a redefinition of property to include intangible assets addresses only the extraordinary case of a non-student spouse whose investment has not yet generated traditional property, and it offers no help for the more ordinary homemaker whose husband has not earned a professional degree or license. The caretaking wife of a nonprofessional employee, for example, would be hardpressed to establish a property right in her husband's job, no matter how senior his position. Expansion of the definition of marital property incompletely answers the problem of the displaced homemaker.

No-fault thus mistakenly assumes that couples will have enough traditional property to allow a court to split that property in a way that will afford equity to a homemaker. The broad judicial discretion afforded trial courts to apportion property only compounds this mistake.

(denying reimbursement alimony to husband who did not incur personal sacrifice to further wife's medical education); and Lehmicke v Lehmicke, $339 \mathrm{~Pa}$ Super 559, 489 A2d 782 (1985) (wife should be compensated for financial support she gave husband while he was medical student). Sometimes such restitution is authorized by statute. See, for example, Ind Code Ann $\$ 31-1-11.5-11$ (West Supp 1992) (authorizing recovery of contributions to tuition, books, and laboratory fees). See also Cal Civ Code $\S 4800.3$ (West Supp 1992) (authorizing reimbursement for education or training that "substantially enhances" earning capacity, but creating a rebuttable presumption that if divorce occurs ten or more years after the contribution, no reimbursement is necessary because the contributing spouse has already benefitted from enhanced earnings). See also La Civ Code Ann, art 121 (West 1992) (authorizing an award for "financial contributions made during the marriage to education or training of his spouse that increased the spouse's earning power, to the extent that the claimant did not benefit during the marriage from the increased earning power"). Such a restitution approach differs significantly from a property classification or maintenance, because restitution will often allow recovery of a sum much smaller than the enhanced earnings of the student spouse.

${ }^{207}$ See Ellman, 77 Cal L Rev at 69 (cited in note 54): "By any modest definition degrees and licenses are not property. Unfortunately, our existing law is so inflexible that some courts thought it necessary to pretend they were, in order to provide a remedy for the woman who was treated like a scholarship." But see Weitzman, The Divorce Revolution at 53 (cited in note 6).

Other commentators have objected to inclusion of a degree or license within the definition of marital property on the ground that it tends to reintroduce notions of involuntary servitude. See Kay, 75 Cal L Rev at 312-13 (cited in note 105). See also Severs v Severs, 426 S2d 992, 994 (Fla App 1983).

Such an objection might be answered by characterizing a claim to enhanced earnings as maintenance which, unlike property, is modifiable upon a showing of changed circumstance. Thus, if a student spouse earned less than anticipated because of death, illness, or other reason, the claim of the non-student spouse might be reduced. See Section III.B., offering a partnership model to support this result. 


\section{Palm-tree justice. ${ }^{108}$}

[T] The discretion of a judge is the law of tyrants; it is always unknown; it is different in different men; it is casual, and depends upon constitution, temper and passion. In the best it is oftentimes caprice; in the worst, it is every vice, folly and passion to which human nature can be liable. ${ }^{109}$

The possibility that a homemaker will receive less than half the marital property at the hands of a trial court vested with broad discretion exacerbates the problem of few assets. Most states have adopted equitable distribution statutes, patterned after the UMDA, which authorize a trial court to divide property in a just, reasonable, or equitable manner. ${ }^{110}$ Often, the only statutory constraint is that a court "consider" certain factors. ${ }^{111}$ Such a directive gives a trial court virtually unfettered discretion. Consequently, a

${ }^{108}$ The term "palm tree justice" refers to the practice of a Moslem Cadi or judge who sits beneath a palm tree dispensing justice according to individual views of fairness.

Freed from compliance with any legal rules or fixed principles, the Cadi does what seems to him to be justice on the facts of the particular case. It may be that no two Cadis would decide any one case in precisely the same way, for individual views of what is fair and just vary more than individual views of the law; yet for that reason it is rarely possible to say with certitude that the decision of any Cadi is wrong.

Nicholas Bala, Judicial Discretion and Family Law Reform in Canada, 5 Canadian J Family $L 15,16$ n 4 (1986).

${ }^{109}$ State $v$ Cummings, 36 Mo 263, 278-79 (1865) (quoting Lord Camden), rev'd, 71 US (4 Wall) 277, 332 (1866). For a more recent discussion of judicial discretion, see Maurice Rosenberg, Judicial Discretion of the Trial Court, Viewed From Above, 22 Syracuse L Rev 635, 637 (1971).

110 There are 40 equitable distribution common law property states. See Doris Jonas Freed and Timothy B. Walker, Family Law in the Fifty States: An Overview, 24 Family L Q 309, 335-36 (1991). Of the ten community property states, three require the equitable distribution of property, and one requires an equal distribution unless inequitable. Id.

The UMDA authorizes a trial court to "equitably apportion" property. UMDA § 307 , 9A ULA 238 (West 1987) (Alternative A). Curiously, while the UMDA purports to adopt a partnership model, it rejects the partnership rule that partnership property be divided "equally" upon dissolution, thus foregoing the bright-line rule of partnership law in favor of deference to trial court discretion.

${ }^{111}$ UMDA \& 307, 9A ULA 238 (West 1987) (Alternative A), directs the court to consider:

the duration of the marriage, and prior marriage of either party, antenuptial agreement of the parties, the age, health, station, occupation, amount and source of income, vocational skills, employability, estate, liabilities, and needs of each of the parties, custodial provisions, whether the apportionment is in lieu of or in addition to maintenance, and the opportunity of each for future acquisition of capital assets and income.

The court must also consider "the contribution or dissipation of each party in the acquisition, preservation, depreciation, or appreciation in value of the respective estates, and the contribution of a spouse as a homemaker or to the family unit." Id.

Notably, while $\S 307$ specifies factors a court should consider, it does not explicitly preclude a court from considering any other factor, except marital misconduct. Moreover, 
court may base its decision on factors outside those listed in the statute or give one listed factor (such as a spouse's greater financial contribution to the marriage) disproportionate and dispositive weight.

Weitzman's data suggest that judges vested with broad discretion may be guided by curious assumptions. She reported an assumption among some trial courts, for example, that "it is fair to divide family income so that the wife and children share one-third, while the husband keeps the other two-thirds for himself."112 Many judges, Weitzman observed, frankly acknowledge a reluctance "to recognize the goodwill in a profession because it would be too difficult for the husband to raise the capital to 'buy back his wife's share." "113 These same courts then minimize the difficulties faced by a long-term homemaker who must raise capital to buy out her husband's share of the home.114

Recently, the attitudes Weitzman observed have been more widely documented in studies reporting gender bias in the courts. ${ }^{115}$ At least thirty states have established task forces to investigate the possibility of gender bias. ${ }^{116}$ Each of the nine states that has published its findings reports that "gender bias detrimental to women permeates every aspect of marital dissolution and child support."117 A New Jersey task force, for example, concluded that despite efforts to achieve gender equity, "New Jersey women of all ages may be the victims of a gender-based maldistribution of earnings and resources at or after divorce."118

A Michigan task force found that the "resolution of economic issues is often premised on misconceptions about the economic

$\S 307$ fails to specify the weight to be given each factor or to define a range of judicial choice. For a criticism of the breadth of judicial discretion allowed under a similar Indiana statute, see text accompanying notes 123-34. For a listing, by state, of statutory factors for judicial consideration, see Freed and Walker, 24 Family $L Q$ at 343-44 (cited in note 110). See also Note, 50 Fordham L Rev at 448-49 (cited in note 32).

112 Weitzman, The Divorce Revolution at 396 (cited in note 6).

113 Id at 397.

114 Id.

118 Michigan Supreme Court Task Force on Gender Issues in the Courts, Conclusions and Recommendations 1 (ca. 1990) (on file with U Chi L Rev). For a discussion of gender bias in New York and elsewhere, see generally Isabel Marcus, Reflections on the Significance of the Sex/Gender System: Divorce Law Reform in New York, 42 U Miami L Rev 55 (1987).

116 Lynn Hecht Schafran, Gender and Justice: Florida and the Nation, 42 Fla L Rev 181,186 \& n 18 (1990).

117 Id at 187.

11 Lynn Hecht Schafran, Documenting Gender Bias in the Courts: The Task Force Approach, 70 Judicature 280, 285 (1987). 
consequences of divorce for women" and that "[s]ome judges and attorneys fail to recognize a spouse's loss of career or career potential as a meaningful contribution to the economic partnership of the marriage."119 A New York task force reported a tendency among trial judges to undervalue homemaker contributions and to ignore the permanent economic loss of women who forego their own careers. ${ }^{120}$ As one legislator poignantly stated:

[Male] perspective on family life has skewed decisions in equitable distribution cases. The perception of most men-and the judiciary is mostly male-is that care of the house and children can be done with one hand tied behind the back. Send the kids out to school, put them to bed, and the rest of the time free to play tennis and bridge. They think any woman-no matter her age or lack of training-can find a nice little job and a nice little apartment and conduct her later years as she might have done at age $25 .{ }^{121}$

To be sure, not all judges entertain such attitudes; sometimes a homemaker receives fair treatment at the hands of a trial court. The financial fate of a homemaker, however, should never depend on the goodwill or prejudice of a particular trial judge. Because the stakes for homemakers are so high, the frequency with which judges dispense unfair treatment is deeply troubling.

To make matters worse, a homemaker cannot expect critical appellate review of an unfair trial court decision. Broad judicial discretion inherently tends to frustrate meaningful appellate review. To prevail on appeal, a spouse must establish that a trial court abused its discretion ${ }^{122}$ - a difficult task indeed when a statute implicitly authorizes a court to rely on personal notions of fairness.

The minimal assets in many marriages, together with the broad discretion afforded trial courts under equitable distribution statutes and the widespread bias against homemaking women, make it unlikely that a one-time division of traditional property

119 Michigan Task Force, Conclusions at 8 (cited in note 115).

${ }^{120}$ Schafran, 70 Judicature at 285 (cited in note 118). The New York task force also reported a pattern of refusal by trial judges to award adequate or timely counsel and expert witness fees to women with no identifiable assets. Id.

${ }^{121}$ Id.

${ }^{222}$ See Homer Clark, The Law of Domestic Relations in the United States 600-01 (West, $2 \mathrm{~d}$ ed 1988). Professor Clark observes that the vague standard of "just" or "equitable" makes it "nearly impossible to generalize from the decisions or to predict their outcome." Id at 601 . See also text accompanying notes 132-34. 
will alone fairly settle the rights of the parties. The Indiana judiciary's application of its equitable distribution statute strikingly demonstrates this reality.

\section{An Indiana story.}

Much like the UMDA, the Indiana equitable distribution statute as originally drafted simply directed a trial court to divide marital property ${ }^{123}$ in a just and reasonable manner. ${ }^{124} \mathrm{~A}$ court was required to "consider" several UMDA-style factors, including the contribution of a spouse as homemaker. ${ }^{125}$ Applying this language in Luedke $v$ Luedke, ${ }^{126}$ the Indiana Supreme Court adopted a posture decidedly unfavorable to homemakers. The trial court had awarded less than half the marital property to a homemaker who had not been employed outside the home for nineteen years. ${ }^{127}$ The disparity in the parties' earning abilities was extreme; Mr. Luedke held a secure, high-paying executive position earning approximately $\$ 100,000$ per year, while Ms. Luedke had no income

123 The statutory definition of marital property in Indiana did not and does not specifcally include a spouse's professional degree, license, or interest in a career. See Ind Code Ann §§ 31-1-11.5-2, 31-1-11.5-11(d) (West Supp 1992). This latter section allows a spouse who has financed her husband's higher education to recover her contribution toward his tuition, books, and laboratory fees. However, even this limited recovery is authorized only where there is little or no marital property. Marital property now specifically includes pension benefits, including benefits that are vested but will not become payable until after the divorce. Ind Code Ann $\S 31-1-11.5-2(d)(2)$ (West Supp 1992). This section was added in 1985 and was hailed as a great victory for homemakers who prior to 1985 could not claim a share of a spouse's pension plan that was not vested, even though the value of the plan was substantial and it was the couple's only asset.

124 Pub L No 297, 1973 Ind Acts 1585, formerly codified at Ind Code Ann § 31-1-11.511.

${ }^{125}$ See id. Former $\S 11$ (b) directed a trial court to consider the following factors:

(1) the contribution of each spouse to the acquisition of the property, including the contribution of a spouse as homemaker.

(2) the extent to which the property was acquired by each spouse prior to the marriage or through inheritance or gift.

(3) the economic circumstances of the spouse at the time the disposition of the property is to become effective, including the desirability of awarding the family residence or the right to dwell in that residence for such periods as the court may deem just to the spouse having custody of any children.

(4) the conduct of the parties during the marriage as related to the disposition or dissipation of their property.

(5) the earnings or earning ability of the parties related to a final division of property and final determination of the property rights of the parties.

Pub L No 180, 1980 Ind Acts 1573, formerly codified at Ind Code § 31-1-11.5-11(b).

128487 NE2d 133 (Ind 1985).

127 Luedke $v$ Luedke, 476 NE2d 853, 855 (Ind App 1985), rev'd 487 NE2d 133 (Ind 1985). 
but hoped to earn $\$ 12,000$ per year after training in respiratory therapy. ${ }^{128}$

In an ill-fated attempt at critical review, the Indiana Court of Appeals held that the trial court abused its discretion in awarding Ms. Luedke less than half the marital assets. The court stated that the equitable distribution statute required a " $50-50$ division of the property between a breadwinner and homemaker, absent a determination by the court that one spouse has seriously neglected his or her role."128 Such a starting point, said the court, would put bite into appellate review. ${ }^{130}$

The Indiana Supreme Court, however, swiftly rejected the concept of a 50-50 starting point, explaining that no language in the statute authorized it. The court added that although a judge perhaps ought initially to lean toward a 50-50 split, a judge could not be required to do so. ${ }^{131}$ Even before Luedke, Indiana appellate judges had complained that a divorce court's broad discretion frustrated meaningful appellate review of property divisions. ${ }^{132}$ After Luedke, one appellate judge concluded that appellate review had become "little more than pretense."133 Two years after the Supreme Court's decision, the Indiana legislature, in 1987, amended its property distribution statute to require a trial court to "presume that an equal division of the marital property between the parties is just and reasonable."134

The Indiana story is encouraging in its demonstration that legislation can limit judicial discretion to award a homemaker less than half of marital assets, but disturbing in its implicit suggestion that in states without such legislation courts can continue to do so. Even when legislation deters the worst abuses of judicial discretion, however, the no-fault assumption that a one-time division of property will afford equity between spouses is a mistake. The minimal assets in most marriages, together with the disparate earning abilities of a homemaker and a breadwinner, suggest that a homemaker should receive something in addition to a share of marital assets. No-fault compounds its first mistake, however, by discouraging a court from awarding maintenance.

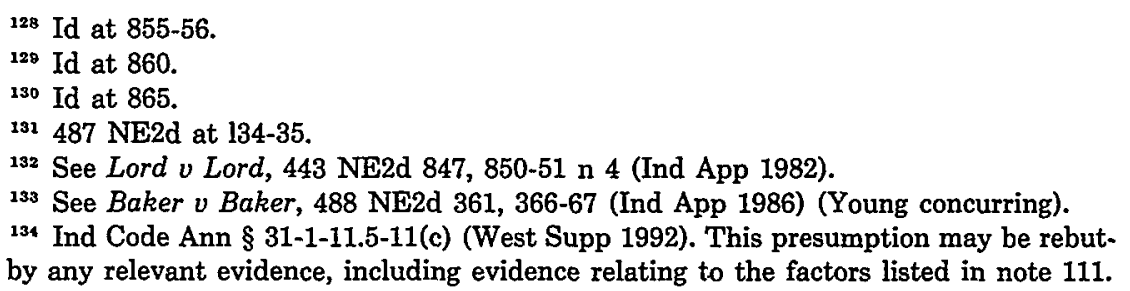


B. Maintenance

Alimony was never intended to assure a perpetual state of secured indolence. It should not be suffered to convert a host of physically and mentally competent young women into an army of alimony drones, who neither toil nor spin, and become a drain on society and a menace to themselves. ${ }^{135}$

Alimony has a terrible reputation. For many, the word triggers nasty visions of the abused male, as indolent young women enjoy a country-club life style at the expense of their hard-working, yet impoverished, ex-husbands. Such visions, though largely mythical, seem close to the core of current no-fault statutes that discourage indefinite maintenance. ${ }^{136}$

\section{Discouraging support.}

The no-fault scheme, explains the UMDA, is "to provide for the financial needs of the spouses by property distribution rather than by an award of maintenance."137 If any maintenance is awarded, courts expect that it should extend for only the limited period necessary to rehabilitate a spouse. ${ }^{138}$ This clean-break scheme mistakenly assumes that marital assets will be sizeable enough to afford equity through the division of property with nothing more ${ }^{139}$ and is overly optimistic about the possibilities for rehabilitation of a homemaker.

a) The rehabilitation illusion. Early on, rehabilitative maintenance seemed to be a solution that could please everyone. If homemakers could be retrained after divorce to become self-supporting, both spouses would be free to begin new lives. Everyone would be happy-financially autonomous homemakers and their non-supporting spouses, feminists shunning the need for male sup-

135 Samuel H. Hofstadter and Shirley R. Levittan, Alimony-A Reformulation, $7 \mathrm{~J}$ Family L 51, 55 (1967).

${ }^{136}$ In this Article, "indefinite maintenance" is used to describe what is often termed "permanent maintenance." The word "permanent" is misleading since permanent maintenance is modifiable and typically terminates upon the occurrence of certain events, such as a woman's remarriage. See Clark, 1 Domestic Relations at 272-93 (cited in note 32).

${ }^{137}$ UMDA § 308 Official Comment, 9A ULA 348 (West 1987). See also the UMDA Prefatory Note which states that "the Act does not continue the traditional reliance upon maintenance as the primary means of support for divorced spouses." Id at 149. But see note 32 and accompanying text. (few divorcing women have ever received maintenance).

138 See UMDA $\S 308(\mathrm{~b}), 9$ A ULA 348 (West 1987).

130 I discuss this problem in Part II.A. of this Article. 
port, and no-fault theorists advocating a clean break at divorce. Inspired by such visions, many state legislatures soon included a provision for rehabilitative maintenance in their no-fault statutes. ${ }^{140}$

Unfortunately, those who work with divorced homemakers now paint a very different picture. "The saddest sight," laments the DHN, "is the middle-aged woman who has been convinced she should go back to school and emerges two or four years older, a well-educated unemployable." ${ }^{141}$ Indeed, some DHN programs decline to refer homemakers for JTPA retraining, since "even with the training they could earn little more than on welfare."142 Thus, in a worst-case scenario, rehabilitative maintenance may ,merely delay a homemaker's descent into poverty. ${ }^{143}$

Even when retraining enables a homemaker to become selfsupporting, she will probably never recapture the loss in earning capacity resulting from time spent in homemaking. Mincer and Polacheck report that women who remain out of the labor market after the birth of their first child suffer a decline in earning capacity of about 1.5 percent per year. ${ }^{144}$ Women with advanced degrees suffer an even higher rate of depreciation. ${ }^{145}$ Most probably, a homemaker's income will never match that of her spouse who participated in the job market without interruption.

In addition to its practical limitations, rehabilitative maintenance unacceptably promotes a "blame-the-victim" perspective that devalues the homemaking role. Indeed, "rehabilitation" is an odd word choice, as if a woman were to be classed along with a criminal who, through rehabilitation, might be able to rise from vice to become a sound, productive citizen.

Pretending that rehabilitative maintenance can "repair" a "damaged" woman by turning back the clock and giving her the

140 In 1971, Florida became the first state legislatively to authorize rehabilitative alimony. David H. Kelsey and Patrick P. Fry, The Relationship Between Permanent and Rehabilitative Alimony, $4 \mathrm{~J}$ Am Acad Matrimonial Lawyers 1, 5 (1988); 1971 Fla Laws 241 $\S 10$, codified at Fla Stat $\S 61.08$ (West Supp 1992). Kelsey and Fry report that as of 1987, at least 29 states had adopted legislation that either authorized rehabilitative alimony or authorized consideration of the length of time needed, for education or training. $4 \mathrm{~J} \mathrm{Am}$ Acad Matrimonial Lawyers at 6.

141 The Displaced Homemakers Network: The Woman It Serves, The Problems It Addresses, Its Accomplishments and Current Activities 2 (pamphlet on file with U Chi L Rev), quoting Laurie Shields.

142 Miller, Working Paper at 11 (cited in note 49).

143 See notes $46-52$ and accompanying text (most displaced homemakers live in poverty).

344 Mincer and Polachek, Family Investments at 415 (cited in note 57).

248 Id. 
career opportunities she had before her marriage is a cruel, if convenient, illusion. Not every woman "can find a nice little job and a nice little apartment and conduct her later years as she might have done at age 25."146 As the following example indicates, entertainment of this rehabilitation illusion sometimes approaches the absurd.

b) Another Indiana story. The Indiana no-fault statute authorizes indefinite maintenance only where a spouse: (1) is physically or mentally incapacitated, or (2) lacks "sufficient" property and is the custodian of a child who is physically or mentally incapacitated. ${ }^{147}$ The ordinary homemaker remains ineligible for indefinite maintenance, no matter how bleak her prospects for economic self-sufficiency or how great her spouse's income. Even in the extraordinary case of physical or mental incapacity of a spouse or child, maintenance is not mandatory but depends on the discretion of a trial court. ${ }^{148}$

Shortly after the Indiana statute was enacted, one concerned appellate judge suggested that a long-term homemaker is incapacitated by definition. "A spouse whose age, lack of education, inexperience and want of vocational skill or training renders him or her only marginally able to support himself or herself might appropriately be held to be 'incapacitated to the extent that the ability ...

146 See Schafran, 70 Judicature at 285 (cited in note 118), quoting a New York legislator's observation of gender-bias in courts.

167 Ind Code Ann § 31-1-11.5-11(e) (West Supp 1992) provides:

(e) A court may make the following findings concerning maintenance:

(1) If the court finds a spouse to be physically or mentally incapacitated to the extent that the ability of the incapacitated spouse to support himself is materially affected, the court may find that maintenance for that spouse is necessary during the period of incapacity, subject to further order of the court.

(2) If the court finds a spouse lacks sufficient property, including marital property apportioned to that spouse, to provide for that spouse's needs and that spouse is the custodian of a child whose physical or mental incapacity requires the custodian to forego employment, the court may find that maintenance is necessary for that spouse in an amount and for a period of time as the court deems appropriate. (emphasis added).

Curiously, this section closely parallels $\S 308$ of the UMDA except that the word "and" (italicized in section (2) above) reads "or" in the UMDA. UMDA § 308(a)(2), 9A ULA 348 (West 1987). This singular change from the text of the uniform act drastically alters the thrust of the statute.

${ }^{168}$ Recently, an Indiana appellate court addressed a trial court's decision to deny maintenance to a 61-year-old disabled wife who divorced after a 35-year marriage. Axsom $v$ Axsom, 565 NE2d 1097 (Ind App 1991). Ms. Axsom received $\$ 432$ in monthly Social Security disability benefits and Mr. Axsom earned approximately \$1,575 per month. Id at 1098 . Stressing that the maintenance decision is discretionary, the appellate court affirmed the trial court's decision. Id at 1099-1100. 
to support himself or herself is materially affected . . . "149 Unfortunately, this view was not adopted by subsequent courts.

As originally enacted, the Indiana statute contained no other provision for maintenance. In 1984, eleven years after implementing no-fault, Indiana amended its statute to authorize a discretionary award of rehabilitative maintenance. ${ }^{150}$ This amendment, however, limited rehabilitative maintenance to a two-year period, ${ }^{151}$ which was extended to three years in $1987 .{ }^{162}$ Because rehabilitative maintenance is discretionary, not all Indiana homemakers receive even this minimal support. Recently, some Indiana trial courts have denied rehabilitative maintenance to long-term homemakers who cannot demonstrate that their education was interrupted because of homemaking or childcare responsibilities. ${ }^{153}$ Indefinite maintenance for the ordinary homemaker remains prohibited. ${ }^{154}$

${ }^{149}$ Liszkai v Liszkai, 168 Ind App 532, 343 NE2d 799, 806 (1976) (Sullivan concurring).

${ }^{150}$ Pub L No 150 § 2,1984 Ind Acts, formerly codified at Ind Code Ann § 31-1-11.511(e)(3):

After considering [the statutory factors]; a court may find that rehabilitative maintenance for the spouse seeking maintenance is necessary in an amount and for a period of time that the court considers appropriate but not to exceed two (2) years from the date of the final decree.

151 Id.

${ }^{152}$ Ind Code Ann $\S 31-1-11.5-11(e)$ (West Supp 1992), as added by 1987 Ind Acts 283 $\S 4$.

${ }^{10 s}$ See In re Marriage of Battles, 564 NE2d 565, 567 (Ind App 1991) (affirming denial of rehabilitative maintenance to military wife who had "substantial opportunity to complete her college degree through university extension courses at various military bases"). See also Dahnke v Dahnke, 535 NE2d 172, 174-75 (Ind App 1989) (reversing trial court denial of rehabilitative maintenance to mother of three children who began college after 14-year marriage).

${ }^{154}$ Professor Joan Krauskopf has recently noted an appellate trend "to preserve indefinite alimony by curbing the excesses of rehabilitative alimony." Joan M. Krauskopf, Rehabilitative Alimony: Uses and Abuses of Limited Duration Alimony, 21 Family L Q 573, 573 (1988). Included in her exhaustive list of cases is In re Marriage of Dillman, 478 NE2d 86 (Ind App 1985), an Indiana case in which the Court of Appeals reversed and remanded a trial court's denial of indefinite maintenance to "a middle-aged delicatessen worker with angina, dizziness, chronic lung disease and recurrent fainting spells." Id at 89. The appellate court was able to reverse that denial, however, only because the trial court made the unusual statement that Indiana law required it to reach an unfair result, a statement that suggested a failure to exercise discretion. Id at 88. Speaking for the appellate court, Judge Young then reiterated the Indiana position that even if the trial court were to find, on remand, an incapacity that materially affected a spouse's ability to support herself, maintenance would not be mandatory. Id at 87. More recently, an Indiana appellate court affirmed a denial of indefinite maintenance after a 35-year marriage to a 61 -year-old wife who was receiving Social Security disability benefits. Axsom, 565 NE2d at 1099-1100. One hopes that Professor Krauskopf is correct in noting a trend toward indefinite alimony, but Indiana decisions do not evidence such a trend. 
Indiana offers a disturbing example of a no-fault maintenance statute that carries the preference for short-term maintenance to an extreme. Equally disturbing is the more typical no-fault statute that authorizes maintenance for longer periods, but ultimately leaves the maintenance decision to the broad discretion of a trial court.

2. Deferring to discretion.

Most no-fault statutes, unlike Indiana's, give a trial court discretion to award indefinite maintenance to a spouse in need. Section 308(a) of the UMDA, for example, provides that a court "may" award maintenance to a spouse who "(1) lacks sufficient property to provide for his reasonable needs; and (2) is unable to support himself through appropriate employment or is the custodian of a child whose condition or circumstances make it appropriate that the custodian not be required to seek employment outside the home."185

Once need is established, however, the amount of any maintenance award is left to the discretion of a judge who must "consider" certain listed factors. Section 308(b) of the UMDA, for example, authorizes a court to order maintenance "in amounts and for periods of time the court deems just, without regard to marital misconduct," after considering the following factors:

(1) the financial resources of the party seeking maintenance;

(2) the time necessary to acquire sufficient education or training to enable the party seeking maintenance to find appropriate employment;

(3) the standard of living established during the marriage;

(4) the duration of the marriage;

(5) the age and the physical and emotional condition of the spouse seeking maintenance; and

(6) the ability of the [paying] spouse ... to meet his needs while meeting those of the spouse seeking maintenance. ${ }^{156}$

Not surprisingly, the broad judicial discretion conferred by section 308 and similar provisions has spawned various decisions that bear little apparent relation to statutory language. Often, judicial application of such statutes has been surprisingly hostile to

${ }^{258}$ UMDA $\S 308(a), 9 A$ ULA 348 (West 1987).

156 UMDA $\S 308(b), 9 A$ ULA 348-49 (West 1987). 
homemakers. The courts of Minnesota provide an example of such a hostile interpretation.

a) Judicial hostility-a Minnesota story. In 1969, Minnesota enacted a no-fault statute with property and maintenance provisions similar to those of the UMDA. ${ }^{167}$ Not surprisingly, the Minnesota Supreme Court soon found within the new law a preference for short-term rather than indefinite maintenance. ${ }^{158}$ In Otis $v$ Otis, the court explained this preference in colorful equality rhetoric:

In recent years, courts have retreated from traditional attitudes toward spousal support because society no longer perceives the married woman as an economically unproductive creature who is "something better than her husband's dog, a little dearer than his horse." Traditionally, spousal support was a permanent award because it was assumed that a wife had neither the ability nor the resources to become self-sustaining. However, with the mounting dissolution rate, the advent of no-fault dissolution, and the growth of the women's movement, the focal point of spousal support determinations has shifted from the sex of the recipient to the individual's ability to become financially independent. This change in focus has given rise to the concept of rehabilitative alimony ....159

157 Minn Stat Ann $\S 518.06$ et seq (West 1990 \& Supp 1992). Section 518.58 provides for the distribution of property. The original version of $\S 518.552$, enacted in 1978 , gave a trial court discretion to award maintenance after considering the following factors:

(a) The financial resources of the party seeking maintenance, including marital property apportioned to the party, and the party's ability to meet needs independently, including the extent to which a provision for support of a child living with the party includes a sum for that party as custodian;

(b) The time necessary to acquire sufficient education or training to enable the party seeking maintenance to find appropriate employment;

(c) The standard of living established during the marriage;

(d) The duration of the marriage;

(e) The age, and the physical and emotional condition of the spouse seeking maintenance; and

(f) The ability of the spouse from whom maintenance is sought to meet his needs while meeting those of the spouse seeking maintenance.

See Minn Stat Ann § 518.552, Historical and Statutory Notes (West 1990).

158 See Otis $v$ Otis, 299 NW2d 114, 116-17 (Minn 1980).

150 Id at 116, quoting Note, Rehabilitative Spousal Support: In Need of a More Comprehensive Approach to Mitigating Dissolution Trauma, 12 USF L Rev 493, 494-95 (1978). The court in Otis reasoned that "if the spouse has the capacity to make her own way through the remainder of her life unassisted by the former husband, then the courts cannot 
Applying this reasoning, the court affirmed an award of only four years of maintenance to a forty-five-year-old homemaker of twenty-four years who had not worked since the birth of the parties' child, twenty-three years earlier. ${ }^{160}$ Although the parties had substantial assets which were essentially split in half, they left the marriage on a decidedly disparate footing. The husband, a vicepresident of a major corporation, earned over $\$ 120,000$ per year plus bonuses; with training, the wife could earn between $\$ 12,000$ and $\$ 18,000$ per year. ${ }^{161} \mathrm{~A}$ dissenting judge argued that Ms. Otis should receive indefinite maintenance in view of her role in fostering her husband's career, ${ }^{162}$ and noted her husband's insistence that she not work while raising a family. ${ }^{163}$

Similar applications followed Otis. In Napier $v$ Napier, the Minnesota Court of Appeals affirmed a temporary maintenance award to a forty-one-year-old homemaker who had only sporadic part-time employment during her nineteen-year marriage. ${ }^{164} \mathrm{Mr}$. Napier earned $\$ 53,000$ per year; Ms. Napier's most recent job paid $\$ 6.00$ per hour. ${ }^{165}$ The court declined to extend the maintenance award notwithstanding the fact that Ms. Napier had only an "outmoded undergraduate degree to present to potential employers" and would "probably never achieve the salary level that she might have had if she had been working full-time during the nineteen years she was married." 166

Again in Rohling $v$ Rohling, the Minnesota Supreme Court affirmed a trial court's refusal to award indefinite maintenance to a sixty-year-old homemaker of twenty-eight years with an eighth grade education. ${ }^{107}$ The court noted that although it might have reached a different conclusion de novo, it was bound to affirm a decision with an "acceptable basis in fact and principle."168

require him to pay alimony other than for rehabilitative purposes." Id, quoting Roberts $v$ Roberts, 283 S2d 396, 397 (Fla App 1973) (emphasis supplied).

$160299 \mathrm{NW} 2 \mathrm{~d}$ at $114-15,117$.

161 Id at 115.

${ }^{182}$ Id at 117-18 (Otis dissenting). When Mr. Otis was interviewed for his current position, for example, Ms. Otis was also interviewed. Id at 118.

${ }^{163}$ Id. Mr. Otis explicitly forbade his wife from working, insisting that he was "not going to have any wife of mine pound a typewriter." Id.

164 374 NW2d 512 (Minn App 1985).

168 Id at 515.

188 Id at 514, 516.

${ }_{167} 379$ NW2d 519, 524 (Minn 1986).

${ }^{168}$ Id. 
Apparently in response to "egregious"169 cases such as Napier and Rohling, the Minnesota legislature amended its statute in 1985 to direct expressly that "[n]othing in this section shall be construed to favor a temporary award of maintenance over a permanent award, where the factors [listed] justify a permanent award." "170 As an added precaution, the legislature stated: "When there is some uncertainty as to the necessity of a permanent award, the court shall order a permanent award leaving its order open for later modification." ${ }^{171}$ This amendment had an immediate impact. Soon after its enactment, the Minnesota Supreme Court reversed a trial court's refusal to award indefinite maintenance to a fifty-six-year-old homemaker of thirty-one years. ${ }^{172}$

The Minnesota experience with UMDA-patterned maintenance provisions is unusual, not because of the hostile interpretation of its judiciary, but because of the intervention of its legislature. Unfortunately, in many other states, courts continue to interpret similar maintenance provisions to the disadvantage of displaced homemakers. ${ }^{173}$ In some states, however, appellate courts have acted without the aid of legislation to reverse hostile trial court application of maintenance statutes. Wisconsin provides an encouraging example of one such state.

b) Judicial sympathy-a Wisconsin story. Wisconsin's no-fault statute, much like the UMDA, gives a trial court broad discretion to order maintenance after considering statutory factors. ${ }^{174}$ In the landmark case of Bahr $v$ Bahr, ${ }^{176}$ the Wisconsin Su-

188 Robert J. Levy, A Reminiscence About the Uniform Marriage and Divorce Act-And Some Reflections About its Critics and its Policies, 1991 BYU L Rev 43, 73-76 (noting the "egregious" history of maintenance in Minnesota).

${ }_{170}$ Act of May 31, 1985, ch $266 \S 52,1985$ Minn Laws 1186, 1186-87 (amending Minn Stat $\S 518.552(1984)$ ). An earlier amendment specifically authorized "either temporary or permanent" maintenance and directed judicial attention to a spouse's ability to become selfsupporting. Act of March 22, 1982, ch $535 \S 1,1982$ Minn Laws at 989. This amendment, however, had little impact. See Levy, 1991 BYU L Rev at 74 (cited in note 169).

1711985 Minn Laws 1186.

172 Nardini v Nardini, 414 NW2d 184, 197-98 (Minn 1987).

173 See, for example, Lovato $v$ Lovato, 98 NM 11, 644 P2d 525, 527 (1982) (reducing alimony to wife who had never worked in order to encourage her to support herself); In re Marriage of Schlenker, 300 NW2d 164, 166 (Iowa 1981) (after 23-year marriage, wife with no employment skills and kidney disorder awarded alimony for only two years).

${ }^{174}$ Wis Stat Ann $\S 767.26$ (West 1981). These factors are:

(1) The length of the marriage.

(2) The age and physical and emotional health of the parties.

(3) The division of property made under section 767.255.

(4) The educational level of each party at the time of marriage and at the time the action is commenced. 
preme Court interpreted this statute to require a trial court to begin the maintenance evaluation "with the proposition that the dependent partner may be entitled to fifty percent of the total earnings of both parties."176 This fifty-fifty starting point enabled the court to reverse an award of only $\$ 1,500$ per month indefinite maintenance, where the husband's annual income was $\$ 313,000$ and the wife's annual income was $\$ 5,000$ or less. ${ }^{177}$ More recently, the fifty-fifty starting point enabled a Wisconsin appellate court to reverse an order requiring a cardiovascular surgeon to pay only 4.6 percent of his income as maintenance to his homemaking wife. ${ }^{178}$

While the Wisconsin courts' attempts to deal fairly with homemakers are encouraging, many other courts remain reluctant to follow suit. So long as no-fault statutes give trial courts virtually unfettered discretion to deny or severely limit maintenance, some trial courts will continue to subject homemakers to unrealistic and gender-biased notions of equity. The mistaken assumption that only a one-time division of traditional marital property can achieve equity compounds this problem of broad judicial discretion. In its eagerness to afford spouses the supposed psychological and economic benefits of a clean break, no-fault overlooks the reality of the sexual division of labor in the home and the cost of that division of labor to the homemaker in the marketplace. The economic

(5) The earning capacity of the party seeking maintenance, including educational background, training, employment skills, work experience, length of absence from the job market, custodial responsibilities for children and the time and expense necessary to acquire sufficient education or training to enable the party to find appropriate employment.

(6) The feasibility that the party seeking maintenance can become self-supporting at a standard of living reasonably comparable to that enjoyed during the marriage, and, if so, the length of time necessary to achieve this goal.

(7) The tax consequences to each party.

(8) Any mutual agreement made by the parties before or during the marriage, according to the terms of which one party has made financial or service contributions to the other with the expectation of reciprocation or other compensation in the future, where such repayment has not been made, or any mutual agreement made by the parties before or during the marriage concerning any arrangement for the financial support of the parties.

(9) The contribution by one party to the education, training, or increased earning power of the other.

(10) Such other factors as the court may in each individual case determine to be relevant.

For an examination of the history of no-fault divorce in Wisconsin, see generally Fineman, 1983 Wis L Rev at 833-86 (cited in note 43).

${ }^{178} 107$ Wis $2 \mathrm{~d} 72,318$ NW2d 391 (1982).

178 Id at 398.

172 Id at $393-98$.

${ }^{178}$ Hubert v Hubert, 159 Wis $2 \mathrm{~d} 803,465$ NW2d 252, 259-60 (Wis App 1990). 
catastrophe this oversight has produced for homemakers has inspired a number of theorists to look beyond band-aid solutions for a new theoretical basis for maintenance.

\section{The Quest for a Conceptual Basis for Maintenance}

Because homemaking is traditionally a female role, the search for a conceptual basis for maintenance is largely a search for a reason to require a husband to share post-divorce income with a wife who has served as primary caretaker. The financial vulnerability of a homemaker cannot alone provide a basis for maintenance. Because a husband who pays maintenance will have fewer resources for himself, ${ }^{179}$ basic fairness counsels against an unreasoned leap from identification of a wife's need to a conclusion that her exhusband should fulfill that need. Maintenance requires a sound theoretical basis. Identification of this basis depends on an understanding of the marriage relationship.

\section{A. The Search Thus Far}

The search for a conceptual understanding of marriage is as old as Blackstone's comment in 1765 that "the husband and wife are one person in law"180 and as new as the current effort of the American Law Institute to formulate a set of principles to guide family law.

1. The historical struggle-Marriage as contract or status?

Early efforts to identify the nature of the marriage relationship focused on whether marriage is a contract or a status. ${ }^{181}$ At the heart of this dispute lay the very practical question of who should fix the terms of the relationship-the parties, the church, or

${ }^{279}$ A husband's resources may be further tapped by his duty to pay child support if he is not the custodial parent. Such a duty would arise independently of the duty to pay maintenance to his spouse, although each obligation affects the other since income is finite. These issues of child support and child custody are beyond the scope of this Article. For a discussion of the ways in which custody decisionmaking disadvantages women, see Fineman, The Illusion of Equality at 79-143 (cited in note 13).

${ }_{180}$ William M. Blackstone, 1 Commentaries *442. Restated in contemporary terms, the common law position was that "husband and wife were one person and that person was the husband." Harry D. Krause, Family Law: Cases, Comments and Questions 175 (West, 3d ed 1990).

181 This issue sometimes sparked heated debate. See, for example, Georg Wilhelm Friedrich Hegel, The Philosophy of Right 32 (Encyclopedia Britannica, 1952) ("To subsume marriage under the concept of contract is thus quite impossible; this subsumption-though shameful is the only word for it-is propounded in Kant's Philosophy of Law.") 
the state. The state ultimately won. As the U.S. Supreme Court observed in 1888, "[m]arriage as creating the most important relation in life, as having more to do with the morals and civilization of a people than any other institution," is "something more than a mere contract."182 Marriage, the Court concluded, "is, rather, a social relation, like that of parent and child, the obligations of which arise not from the consent of concurring minds, but are the creation of the law itself ...." ."183

This view of marriage as something more than a purely consensual relationship afforded the necessary basis for extensive state regulations. Such regulations prescribed the age, race, sex, and number of marital partners, the incidents of solemnization and licensing, and the rights and obligations of the parties. ${ }^{184}$ Even the parties' ability to terminate their relationship was strictly regulated through laws that limited divorce to cases of serious marital fault. ${ }^{185}$ Very little was left to party autonomy.

In the years following World War I, traditional reverence for the institution of marriage began to yield to a new emphasis on individual fulfillment. ${ }^{186}$ This new emphasis seemed at odds with extensive state regulation of marriage, and seemed especially inconsistent with fault-based divorce laws, which often limited individual choice. ${ }^{187}$ This uneasy tension, together with the equality rhetoric of the emerging women's movement, signalled the need for a new model of marriage.

${ }^{182}$ Maynard v Hill, 125 US 190, 205, 210-11 (1888). See also Low v Peers, Wilmot 364, 371, 97 Eng Rep 138, 141 (Ex Ch 1770) (observing that marriage was "one of the first commands given by God to mankind after the Creation, repeated again after the Deluge, and ever since echoed, by the voice of Nature, to all mankind").

183 Maynard, 125 US at 211.

${ }^{184}$ See Friedrich v Katz, 34 NY2d 987, 360 NYS2d 415, 318 NE2d 606, 606 (NY App Div 1974) (minimal age and parental consent); Loving $v$ Virginia, 388 US 1, 10-11 (1967) (same race), overruling Loving $v$ Commonwealth, 206 Va 924, 147 SE2d 78 (1966); Baker $v$ Nelson, 191 NW2d 185, 187 (Minn 1972) (different sexes); Reynolds $v$ United States, 98 US (8 Otto) 145, 161-68 (1878) (one spouse at a time); Larson v Larson, 42 Ill App 2d 467, 192 NE2d 594, 597-98 (1963) (solemnization and licensing); and Carabetta v Carabetta, 182 Conn 344, 438 A2d 109, 110-15 (1980) (solemnization and licensing). For a general discussion of state regulation of marriage, see Krause, Family Law ch 1 (cited in note 180). For a discussion of the prohibition against same-sex marriages, see Mary Patricia Treuthart, Adopting a More Realistic Definition of "Family", 26 Gonzaga L Rev 91 (1990/91).

${ }^{185}$ For a discussion of the history of divorce laws, see O'Connell, 23 New England L Rev at 444-71 (cited in note 31 ).

186 Id at 475-83. For a discussion of the declining importance of family during this period and later, see generally Mary Ann Glendon, The New Family and the New Property (Butterworths, 1981).

${ }^{187}$ See notes 33-38 and accompanying text. 
2. The UMDA model-The birth of partnership marriage.

The UMDA response to the old debate over contract and status was to define marriage as a "personal relationship between a man and a woman arising out of a civil contract to which the consent of the parties is essential." 188 This definition of marriage as a status arising out of a contract seems to incorporate rather than resolve the contract-status debate. More helpful is the drafters' brief reference, in a prefatory note, to a partnership model for divorce. ${ }^{189}$ Though its rationale is not clearly articulated, the UMDA suggests a view of marriage as a consensual relationship, the dissolution of which, in the absence of an agreement otherwise, ${ }^{190}$ should be governed by legislatively-supplied rules similar to those of partnership law.

At the core of this partnership model are two simple concepts: divorce should be available at will; and divorce should terminate the parties' mutual responsibilities, thus affording each party an emotional and financial clean break. Adherence to this clean-break principle of partnership law, however, without regard to related partnership principles essential to its fair application, made divorce a financial disaster for homemakers. The partnership model for marriage soon became a convenient scapegoat.

Contemporary theorists attacked the partnership metaphor for its failure to provide a conceptual basis for maintenance, ${ }^{191}$ its mischaracterization of marriage as "profit-seeking,"192 its hidden bias

${ }^{188}$ UMDA $\S 201$, 9A ULA 160 (West 1987). That section further states: "A marriage licensed, solemnized, and registered as provided in this Act is valid in this State. A marriage may be contracted, maintained, invalidated, or dissolved only as provided by law." Id. The drafters' comment explains that this section "emphasizes the legal concept of marriage as a civil contractual status, in distinction from any religious significance also attached thereto." Id at 161 .

180 UMDA, Prefatory Note, 9A ULA 149 (West 1987). The Note states, in pertinent part: "The distribution of property upon the termination of a marriage should be treated, as nearly as possible, like the distribution of assets incident to the dissolution of a partnership." Id. Reference to a partnership model of marriage does not otherwise appear in the text or comments of the UMDA.

${ }^{190}$ See UMDA § 307, 9A ULA 238 (West 1987) (Alternative A) (recognizing, by implication, the validity of premarital agreements).

${ }^{191}$ Professor Ira Mark Ellman, for example, maintains that partnership law authorizes post-dissolution compensation only where the dissolution is "wrongful" or where a partner has provided either extraordinary or inadequate service. Ellman, $77 \mathrm{Cal} \mathrm{L} \mathrm{Rev} \mathrm{at} \mathrm{35-40}$ (cited in note 54). He" concludes that "[p]artnership makes no provision for alimony." Id at 35. See also Stephen D. Sugarman, Dividing Financial Interests on Divorce, in Divorce Reform 130, 140 (cited in note 41) ("under the partnership analogy there would be no spousal support"). But see Section III.B. for an explanation of how partnership law does provide a conceptual basis for maintenance.

${ }^{192}$ See Ellman, 77 Cal L Rev at 33 (cited in note 54). 
against women, ${ }^{193}$ and its failure to recognize the different ways in which a business partnership and a marital relationship commence. ${ }^{184}$ Those theorists who rejected the partnership model, together with those who tacitly dismissed it, launched a search for a framework that would provide a conceptual foundation for maintenance.

\section{Post-UMDA models-The return to contract.}

In the twenty years since promulgation of the UMDA, the belief that a partnership model provides no satisfactory basis for maintenance has spawned numerous inquiries. Many of these inquiries look to contract for a theoretical basis for maintenance, though without expressly advocating a pure contract model of marriage. ${ }^{105}$

a) Protecting contractual interests. The inquiries of post-UMDA theorists have produced several frameworks for maintenance that rest ultimately on one or more of the traditional contract interests of restitution, reliance, and expectation. ${ }^{196}$ Several of these inquiries into contract have laid important groundwork for a new conceptual basis for maintenance. None, however, has adequately explained and quantified maintenance for the typical wife, whose primary caretaking responsibilities during marriage restrict

${ }^{20 s}$ See O'Connell, 23 New England L Rev at 497-98 (cited in note 31). Professor O'Connell reasons that if each partner walks away from a business partnership with $50 \%$ of the assets, theoretically each has an equal opportunity for future success. In contrast, a woman usually does not leave a marriage with an equal opportunity for future success. Data suggest that she is economically damaged by participation in a failed marriage. Id at $497 \mathrm{n}$ 342. See also Fineman, The Illusion of Equality at 176 (cited in note 13) ("As it currently stands, the partnership concept of sharing responsibility and contribution is typically translated into assuming equal economic responsibility after divorce, a result that is unrealistic, even cruel, given the material situation of many women.").

194 Professor Mary Ann Glendon, for example, observes that while business partners typically negotiate a general agreement governing the terms of the partnership, including dissolution, marriage partners relegate the crucial terms of partnership to tacit assumption. Glendon, The New Family at 65 (cited in note 87).

195 Although Professor Marjorie Shultz has made a persuasive argument for conceptualizing marriage as contract, her effort does not focus on the efficacy of such a model for addressing income disparity on divorce. See Marjorie Maguire Shultz, Contractual Ordering of Marriage: A New Model for State Policy, 70 Cal L Rev 204 (1982).

196 Traditionally, these three remedies have been used to accomplish the following goals: restore any benefit conferred by an injured party (restitution); return an injured party to the position it would have held had the contract not been made (reliance); and give an injured party the benefit of its bargain (expectation). See E. Allan Farnsworth, Contracts $\S$ 12.1 at 151-52 (Little, Brown, 1990). 
her career opportunities and advancement, thus limiting her postdivorce income potential.

(1) A restitution model. The simplest basis for maintenance is a restitution model. The classical contract remedy of restitution protects a promisee's "interest in having restored to him any benefit that he has conferred on the other party." ${ }^{197}$ Restitution thus prevents unjust enrichment by requiring a party in breach to disgorge any benefit conferred by the other party. ${ }^{198}$

When applied to the marital relationship, the goal of restitution easily supports a rule requiring one spouse to reimburse the other for financial contributions. ${ }^{198} \mathrm{~A}$ wife who has financed the cost of her husband's education, for example, would be reimbursed for the sums she contributed to his tuition, books, and laboratory fees. ${ }^{200}$ Such a limited payback, however, grossly undercompensates a wife when both spouses expected a high rate of return on their joint investment. A medical education, for example, is worth much more than tuition and laboratory fees. This backward focus on contribution rather than expected return, however, is the essence of the restitution interest.

An expanded restitution model could include intangible, nonmarket contributions associated with caretaking to compensate a wife more fairly for benefits she conferred on her husband. This approach, however, raises serious problems of valuation. Attempts to quantify the value of caretaking are troublesome both in their entertainment of the fiction that these contributions have an objective, marketable value and in the litigation costs generated by the need to determine the kind, extent, and value of benefits conferred in a specific case. ${ }^{201}$ Moreover, one theorist claims that these "ordinary" marital benefits are not properly recoverable under a

${ }^{197}$ Restatement (Second) of Contracts § 344(c) (1979).

${ }^{108}$ See Farnsworth, Contracts $\S 12.1$ at 151 (cited in note 196).

198 See, for example, Leonard Charles Schwartz, Divorce and Earning Ability, 1982 Detroit Coll L Rev 69, 76.

${ }^{200}$ Some states, by statute, protect a spouse's restitution interest by requiring reimbursement for contributions to education. See, for example, Ind Code Ann § 31-1-11.5-11(d) (West Supp 1992).

${ }^{201}$ For an attempt to avoid this valuation problem by basing a homemaker's recovery on the percentage of homemaking chores undertaken, rather than their value, see Comment, Contracting for Security: Paying Married Women What They've Earned, $55 \mathrm{U}$ Chi L Rev 1193, 1222-23 (1988). 
restitution model since they usually are conferred with donative intent and are thus not unjustly retained. ${ }^{202}$

As a practical matter, a restitution model thus serves a very narrow function. It provides a basis for minimal maintenance and then only where one spouse has conferred a quantifiable financial benefit on the other, usually by underwriting the cost of education.

(2) A reliance model. A reliance model provides a broader foundation for maintenance. This model seeks to protect a promisee's "interest in being reimbursed for loss caused by reliance on the contract by being put in as good a position as he would have been in had the contract not been made." ${ }^{203}$ A reliance remedy thus protects the party who has "changed position in reliance on the contract by incurring expenses in preparation or in performance." 204

An unsettled issue in contract law today is whether recovery based on reliance may sometimes include opportunity costs, i.e., damages based on opportunities lost because of reliance on a promise. ${ }^{205}$ For example, an employee who accepts full-time employment with one employer cannot accept full-time employment with a second employer. If the first employer breaks the contract, the employee might claim damages based on loss of the opportunity to work for the second employer. Damages based on opportunity costs "attempt to put the injured party in the position in which that party would have been had that party made the best alternative contract to the one that was broken."206 While inclusion of lost opportunities in reliance damages has intrigued contracts scholars, courts have largely ignored them. ${ }^{207}$ Nevertheless, opportunity costs have become a favorite rationale of those in search of a theoretical basis for maintenance.

In its narrowest form, a model based on lost opportunities explains maintenance for purposes of rehabilitation. Rehabilitative maintenance aims to compensate a spouse for the lost opportunity

202 See Ellman, $77 \mathrm{Cal} \mathrm{L} \mathrm{Rev} \mathrm{at} \mathrm{24-27} \mathrm{(cited} \mathrm{in} \mathrm{note} \mathrm{54).} \mathrm{Under} \mathrm{this} \mathrm{reasoning,} \mathrm{only}$ benefits extraordinary enough to suggest non-donative intent would be reimbursed. See id at 26-27. Distinguishing extraordinary benefits from merely ordinary ones is, of course, no easy task and would invite a court to depend upon "its own sense of the obligations and claims necessarily flowing from marriage." Id at 27.

${ }^{203}$ Restatement $\S 344(b)$ (cited in note 197).

204 Farnsworth, Contracts $\S 12.1$ at 149 (cited in note 196).

${ }^{20 s}$ See id $\S 12.16 a$ at $266-71$.

208 Id at 267.

207 See id. 
to prepare for remunerative employment. Its goal is thus limited to the training or education of a spouse who seeks to enter the job market for the first time or after a period of nonremunerative employment. ${ }^{208}$ Rehabilitative maintenance makes no attempt to reimburse a spouse for the lost opportunity to make an uninterrupted, non-distracted, long-term investment in employment. A rehabilitation model thus contemplates only short-term maintenance and fails to reimburse fully a spouse for her reliance on the marital relationship or the loss of her pre-marital opportunities.

A more generous model based on lost opportunities might seek to compensate a spouse fully by placing her in her pre-marital position and compensating her for all opportunities lost in reliance on the marriage relationship. ${ }^{209}$ Maintenance in such cases would recompense the homemaker whose career opportunities and advancement were limited because of caretaking responsibilities. Such an approach faces practical roadblocks. Most obviously, it is difficult to identify the comparative baseline of a spouse's "best alternative contract." 210 If she had not married her husband, would a wife have remained single? Would she have become a secretary, a law professor, or a neurosurgeon? Would she have married a secretary, a law professor, or a neurosurgeon? Would an alternative husband have forbidden her to work, encouraged her career, or been

${ }^{203}$ See UMDA \& 308(b)(2), 9A ULA 348 (West 1987) (trial court ordering maintenance should consider "the time necessary to acquire sufficient education or training to enable the party seeking maintenance to find appropriate employment").

${ }^{208}$ See Margaret F. Brinig and June Carbone, The Reliance Interest in Marriage and Divorce, 62 Tulane L Rev 855 (1988). Professors Brinig and Carbone reason: "In modern marriages the reliance interest has become more complex. It embraces a lost opportunity to marry someone else, valued differently for different people during different times during the marriage, together with the sacrifices in career development that would never have been an issue in a society of single career families." Id at 881. See also Kay, Beyond No-Fault at 3334 (cited in note 89) (suggesting recognition of wife's loss of earning capacity combined with reimbursement alimony).

210 See the definition of lost opportunity at text accompanying notes 205-07. Professor Ellman has suggested that lost opportunities might be measured by the difference between a woman's actual earning capacity when the marriage ends and the earning capacity she would have achieved if she had remained single. See Ellman, 77 Cal L Rev at 54 (cited in note 54). This measure would not, however, avoid the troublesome problems of speculation. As Professor Ellman concedes, "determining the earning capacity she would have had may be very difficult. In fact, in some sense it is impossible even in theory, as is any 'might have been." "Id at 78. "In the end," Professor Ellman concludes, "precision is not obtainable. The determination of alimony claims, even more than most legal questions, will necessarily depend, at least in part, upon the rough justice of trial judge discretion." Id at 80 . For a discussion of the dangers inherent in such judicial discretion, see text accompanying notes 155-73. For an argument that Professor Ellman's model is actually grounded in restitution principles, see June Carbone, Economics, Feminism, and the Reinvention of Alimony: A Reply to Ira Ellman, 43 Vand L Rev 1463, 1471-85 (1990). 
indifferent to her aspirations? Would she have remained married indefinitely? Such endless speculation dooms any effort to measure actual lost opportunities. Therefore, although a reliance model may help in identifying circumstances in which maintenance seems appropriate, it offers little guidance in measuring loss.

(3) An expectation model. Another model, based on the expectation interest, comes from human capital theorists. ${ }^{211} \mathrm{~A}$ favorite measure of recovery in contract, expectation protects a party's "interest in having the benefit of his bargain by being put in as good a position as he would have been in had the contract been performed." 212

When applied to marriage, expectation is measured by a wife's expected return on her investment in the human capital of her husband. Professor Joan Krauskopf explains that investments in human capital are "[e]xpenditures to acquire or to increase a person's skills or knowledge that lead to increased future productivity."213 Marriage offers a classic illustration of such an investment in human capital when a wife supports her husband while he obtains a professional education, a scenario addressed by most writing on this theory. In such a case, the marital unit makes an investment. The wife finances her husband's education, often in combination with homemaking and child care, foregoing possible opportunities to increase her own human capital through educational investment; the husband invests in his own human capital, foregoing possible opportunities for remunerative employment

212 Human capital concepts, which date to the time of Plato, have enjoyed great popularity among economists since the early 1960s. Krauskopf, $28 \mathrm{Kan} \mathrm{L} \mathrm{Rev} \mathrm{at} 381$ (cited in note 96). Theorists who advocate the application of human capital concepts to marriage include: Deborah A. Batts, Remedy Refocus: In Search of Equity in "Enhanced Spouse/ Other Spouse" Divorce, 63 NYU L Rev 751 (1988); Elizabeth S. Beninger and Jeanne Wielage Smith, Career Opportunity Cost: A Factor in Spousal Support Determination, 16 Family L Q 201 (1982); E. Raedene Combs, The Human Capital Concept as a Basis for Property Settlement at Divorce, 2 J Divorce 329 (1979); Krauskopf, 28 Kan L Rev 379 (cited in note 96); Elisabeth M. Landes, Economics of Alimony, 7 J Legal Stud 35 (1978); and Allen M. Parkman, The Recognition of Human Capital as Property in Divorce Settlements, 40 Ark L Rev 439 (1987). Not all of these theorists advocate human capital theory as a basis for maintenance. For example, Professors Parkman and Combs urge that human capital is property that should be valued and divided like other marital property on divorce. See Parkman, 40 Ark $\mathrm{L} \mathrm{Rev}$ at 440-41 (income stream expected for future services is an asset, like a house); Combs, $2 \mathrm{~J}$ Divorce at 333 (earning ability is an asset to be divided).

212 Restatement $\$ 344$ (a) (cited in note 197). A noneconomic model based on expectation might support an equal division of post-divorce income. Such a model, designed straightforwardly to encourage sharing in marriage, is offered by Professor Jane Rutherford, Duty in Divorce: Shared Income as a Path to Equality, 58 Fordham L Rev 539, 578 (1990).

213 Krauskopf, $28 \mathrm{Kan} L \mathrm{Rev}$ at 381 (cited in note 96). 
during his education. ${ }^{214}$ The parties expect that the marital unit will enjoy a return on this investment, though only the husband recognizes a greatly enhanced earning capacity. If the parties divorce, human capital theorists contend that the wife should receive a return on her investment.

Although human capital theory's emphasis on reimbursement for capital contributions suggests restitution, and although its lostopportunity focus suggests reliance, its preferred measure of recovery clearly marks this theory as one based on expectation. ${ }^{215}$ As Professor Krauskopf counsels, "[i]n determining the amount of the award, the court should consider not only restitution for the monetary contribution, but also fulfillment of the expectation of return in proportion to the amount of investment." the award based on "the amount of capitalized earnings attributable to the additional education."217 This forward focus defines the traditional contract interest of expectation.

Human capital theory improves on reliance theory by offering not only a means of identifying appropriate cases for maintenance but also the practical tools for measuring an award. Human capital theorists, however, tend to focus on the extraordinary case rather than the ordinary one. These theorists often offer human capital theory as a solution to the problem of a spouse who finances her husband's professional education and then is divorced before that education begins to generate enhanced earnings. The notion of an investment in human capital, however, need not be restricted to these extraordinary cases. Indeed, one of the earliest proponents of human capital theory in marriage, Professor Elisabeth Landes, laid the groundwork for a much broader view of investment. ${ }^{218}$

214 See id at 384,387 . Such an investment in a graduate degree may be intrinsically enjoyable, on net, for the student, but far less so for the spouse supporting the student.

225 That human capital theory contains elements of all three of the traditional contract remedies is evidenced by Professor Krauskopf's statement that "[t]raditional legal principles of honoring expectations of return [expectancy interest] for investment [reliance interest] and of preventing unjust enrichment [restitution interest] apply to the dissolution of a marriage in which one spouse has invested in the other spouse's education." Id at 416.

${ }^{218}$ Id at 417 (emphasis added).

217 Id at 382 .

218 Landes, $7 \mathrm{~J}$ Legal Stud at 40 (cited in note 211). Professor Landes reasoned that "[b]y spending time in household production, a wife directly frees some of her husband's time to the market, increasing both his current market earnings and his incentive to invest in earnings-augmenting skills." Id. See also Sugarman, Dividing Financial Interests, in Divorce Reform 130, 159-60 (cited in note 191) (offering a model based on "merger over time" in which the longer parties are married, "the more their human capital should be seen as intertwined rather than affixed to the individual spouse in whose body it resides"). A model 
While many of the models developed over the past twenty years explain maintenance in certain circumstances, none has provided a satisfactory foundation for maintenance for the ordinary homemaker whose primary caretaking responsibilities preclude or limit her participation in the job market, thereby restricting development of her human capital. A better model is needed. The repeated focus of theorists on contract interests suggests that a new search might well begin by asking why these theorists have advocated contract measures of loss while shunning straightforward adoption of a contract model, and whether such a model would offer a better basis for maintenance than a piecemeal application of contract principles.

b) Shunning a contract model. The reluctance of many theorists to view marriage as a contract seems curiously inconsistent with the recent trend toward recognizing and enforcing prenuptial agreements, ${ }^{219}$ and with the emerging literature on relational contract theory. ${ }^{220}$ This resistance to contract seems to stem largely from a series of misperceptions and negative images of contract.

for maintenance based on Landes's expansive view of investment in human capital, and grounded in an analogy to partnership law, is presented in Part IV of this Article.

${ }^{210}$ See generally Ellman, Kurtz, and Bartlett, Family Law at 661-67 (cited in note 32). The seminal case recognizing a premarital agreement is Posner $v$ Posner, 257 S2d 530 (Fla 1972). In 1983, a Uniform Premarital Agreement Act ("UPAA") was promulgated that allows spouses to contract concerning maintenance and any other matter "not in violation of public policy or a statute imposing a criminal penalty." UPAA § 3, 9B ULA 373 (West 1987).

220 Relational theory rejects the classical view of a contract as a discrete transaction "entirely separate not only from all other present relations but from all past and future relations as well." Ian R. Macneil, Contracts: Adjustment of Long-Term Economic Relations Under Classical, Neoclassical and Relational Contract Law, $72 \mathrm{Nw}$ U L Rev 854, 856 (1978). Relational theorists stress that a contractual relationship is fundamentally rooted in society. See Ian R. Macneil, The New Social Contract 14-15 (Yale, 1980). Contracts, especially long-term contracts, thus depend to a large degree on external, social standards that can be used to fill gaps in the parties' agreement. Relational contract theory therefore seems to embrace a view of marriage as both status and contract-external standards usually fix the terms of the relationship that begins through mutual consent, a view strikingly similar to the UMDA conceptualization of marriage as a relationship springing from a contract. See note 188 and accompanying text. See also Krause, Family Law at 92 (cited in note 180) ("Marriage is a contract and a status ... [M]arriage is a contract in the sense that it is entered into somewhat like a contract and that, at least to some extent, it may be modified by the parties' private contract. The marriage relationship is a "status" because a large set of rules is thrust upon the spouses without their specific agreement."). 
Contract is sometimes thought to be too crass or too masculine a model for a relationship as venerable as marriage. ${ }^{221}$ Viewing an ongoing marriage as a purely contractual relationship might be said to promote an alienated, cynical view of marriage that debases its intimate nature. Defining marriage as a contract, however, hardly accomplishes this insidious result. A contract is simply a consensual relationship grounded in an exchange of promises, ${ }^{222}$ or mutual commitments, ${ }^{223}$ a definition that accurately, if generally, describes the marital relationship. Once a contract is formed, the law usually seeks to protect the parties' expectations rather than to compel them to perform their promises, ${ }^{224}$ a focus consistent with protection of the spouses' financial expectations while authorizing divorce at will. At least in these fundamental ways, contract thus reflects rather than debases normative views of marriage.

Additional reluctance to view marriage as a contract stems from fear that recognizing intimate contracts governing ongoing marriages would flood the courts with actions to enforce the detailed terms of such contracts. ${ }^{225}$ However, because spouses, like parties to a commercial contract, rarely attempt to detail the terms

${ }^{221}$ See Maynard, 125 US at 205, 211 (marriage is more than a "mere" contract; it creates the most important relation in life). See also James C. Foster, Antigones in the Bar: Woman Lawyers as Reluctant Adversaries, 10 Legal Stud F 287, 288 (1986) ("The quintessential male world of law [is] profoundly shaped by formal-rational, contractarian ... underpinnings of American social reality, and . . . by the psycho-sexual roots of patriarchy.").

${ }_{222}$ See Farnsworth, Contracts $\S 1.1$ at 4 (cited in note 196) (defining a contract as "a promise or set of promises, that the law will enforce or at least recognize in some way").

${ }^{223}$ See Restatement $\S 2(1)$ (cited in note 197) (defining promise as "a manifestation of intention to act or refrain from acting in a specified way, so as to justify a promisee in understanding that a commitment has been made").

224 See generally Farnsworth, Contracts $\$ 12.1$ (cited in note 196).

${ }^{225}$ Professor Weitzman is the primary advocate of express intimate agreements concerning day-by-day conduct during marriage. See Lenore J. Weitzman, The Marriage Contract 227-54 (Free Press, 1981). Such domestic contracting, argues Weitzman, allows parties to tailor the terms of their relationship to meet their individual needs and values. Id at xxi. For a criticism of Weitzman's position based on its alleged tendency to promote litigation, see Marsha Garrison, Marriage: The Status of Contract, 131 U Pa L Rev 1039, 1053 (1983) (reviewing Weitzman, The Marriage Contract). 
of their daily interactions, ${ }^{226}$ enforcement of intimate contracts is largely a mythical problem. ${ }^{227}$

Most importantly, a contract model for marriage has been rejected because it allegedly offers no basis for maintenance. Professor Ira Mark Ellman, for example, reasons that a contract model contradicts the concept of no-fault, since it would require conceptualizing maintenance as an award of damages for breach. ${ }^{228}$ While it is true that maintenance cannot be analogized to damages for breach of contract if the spirit of no-fault is to be honored, damages are not the only obligation that may arise when a contractual relationship ends. In some cases, parties may expressly agree that termination triggers a duty of alternative performance, such as a buyout, quite apart from damages. ${ }^{229}$ In the absence of an express agreement requiring a buyout, such a duty may be imposed by statute. ${ }^{230}$ In other cases, a court may impose a duty to pay money that is based not on breach, but on notions of justice and fair

${ }^{226}$ Spouses fail to detail the terms of their ongoing relationship or to enter prenuptial agreements governing its termination for many of the same reasons that parties to commercial contracts fail to do so. For example, parties sometimes may fail to foresee an event. At other times, they may foresee it, but may believe it is unlikely to arise. Or, they may be reluctant to raise a matter, especially a delicate one, that may result in delay, disclosure of facts they prefer to keep secret, addition of an unfavorable provision, or even the loss of the contract. See Farnsworth, Contracts $\S 7.15$ at $299-300$ (cited in note 196). Finally, parties may fail to negotiate terms because they are confident the law will supply them if they are needed. Id. In the case of marriage, the reluctance of most spouses to enter such intimate contracts suggests a view that it might be better to rely on the courts for fair allocation, rather than to engage in quasi-adversarial bargaining with the spouse to whom one may currently be deeply devoted.

${ }^{227}$ Even if detailed intimate contracts become more popular, courts might decline to entertain actions for enforcement of details on the ground that public policy necessitates limiting indiscriminate access to the courts. Public policy has long been recognized as a legitimate basis for curtailing party autonomy, even in clearly recognized contractual relationships. See Farnsworth, Contracts $\$ \S 5.2-5.4$ (cited in note 196). See also Arthur Linton Corbin, 6A Corbin on Contracts $\$ 1373-78$ (West, 1962).

${ }^{228}$ Ellman, $77 \mathrm{Cal} \mathrm{L} \mathrm{Rev} \mathrm{at} 16$ (cited in note 54). Professor Ellman suggests that the contract model may simply be a guise for reintroducing fault into divorce proceedings. Id at 23-24.

${ }^{229}$ For example, sports contracts and partnership agreements may contain buyout clauses that put a price tag on a party's decision to leave the relationship. See John J. Chapman and Arthur M. Gans, National Hockey League Contract Negotiations, in Gary A. Uberstine, ed, The Law of Professional and Amateur Sports, 8-1, 8-10 (Clark Boardman, 1988) (standard player contract provides that a club may terminate relationship at any time without cause by buying out the contract).

2s0 The Uniform Partnership Act ("UPA"), for example, sometimes requires a buyout of the interest of a departing partner. This buyout duty is expended in recent drafts of the Revised Uniform Partnership Act ("RUPA"). See RUPA § 701. In 1987, the National Conference of Commissioners on Uniform State Laws appointed a Drafting Committee to revise the UPA and named Dean Donald J. Weidner as reporter. This Article cites the October 28, 1992 draft (without comments) of RUPA and the comments to the August, 1991 draft. See 
play. ${ }^{231}$ In the case of marriage, a concern for fair play might support imposition of a duty to pay maintenance.

Such a duty to pay maintenance might be imposed through judicial gap-filling. The failure of most spouses to enter prenuptial agreements leaves a gap in the marriage contract as to many incidents of their relationship. Contract law teaches that such gaps may be filled in several ways. If a court is unable to massage express terms into yielding a necessary term, ${ }^{232}$ it may struggle to determine the parties' supposed expectations and supply a term implied-in-fact on this basis. ${ }^{233}$ If these efforts fail, a court may supply a term based on the parties' hypothetical expectations-the expectations the parties presumably would have agreed upon if they had considered the matter. ${ }^{234}$ Alternatively, a court may supply a term that is "reasonable in the circumstances,"235 and comports with "community standards of fairness and policy."236 So guided, courts generally supply terms based on a duty to act in good faith and in accord with general notions of fair dealing. ${ }^{237}$ In the case of marriage, such a reasonable term might include a husband's promise to pay maintenance to a wife who serves as primary caretaker, thus providing a nurturing, non-distracting environment

UPA § 38(2), 6 ULA 456 (West 1969); UPA $\S 42,6$ ULA 521 (West 1969); RUPA § 701. For a discussion of buyouts, see text accompanying notes 264-71.

${ }^{231}$ One example is the case of a franchisor who is sometimes required to compensate a franchisee at the end of their relationship. Such compensation is not based on breach since the relationship is at-will, but rather on notions of fair dealing. Farnsworth, Contracts $\$ 7.17$ at $318,320-22$ (cited in note 196).

${ }^{232}$ See generally id at $\S 7.17$.

${ }^{233}$ The search for an implied-in-fact term requires a court to speculate whether the parties actually share a common expectation or, lacking that, whether one party had an expectation that the other party should reasonably have known. See id. Often, this focus induces a court to entertain the fiction that the parties agreed to a term that in fact they never considered. In the case of marriage, such a search would be troublesome because as long as a marriage is proceeding smoothly, most couples do not actually contemplate termination. Those who do so prior to marriage are likely to enter prenuptial agreements.

${ }^{234}$ See Farnsworth, Contracts $\$ 7.16$ at 306 (cited in note 196). In the case of marriage, an argument could be made that if the parties, at the time of their marriage, had contemplated the termination of their relationship, their presumed mutual affection would have led them to settle on "fair" terms. See note 226 and accompanying text. By contrast, in a purely commercial contractual relationship, self-interest, rather than fairness, may more accurately describe the parties' hypothetical expectations.

${ }^{238}$ Restatement $\$ 204$ (cited in note 197). See also the following gap-fillers in the Uniform Commercial Code: $\S 2-309$ (1) (reasonable time for performance) and § 2-305 (reasonable price at time of delivery).

${ }_{236}$ Restatement $\$ 204$, comment d (cited in note 197).

${ }^{237}$ See id at \$ 205: "Every contract imposes upon each party a duty of good faith and fair dealing in its performance and its enforcement." See also UCC § 1-203: "Every contract or duty within this Act imposes an obligation of good faith in its performance or enforcement." 
that fosters development of his human capital and limits development of her own. Determining whether such a promise to pay maintenance is appropriate in a specific case, and if so the amount of such maintenance, ultimately would depend, however, on a court's personal sense of justice and fair play.

While none of the reasons commonly offered for rejecting a contract model is persuasive, no compelling reason exists to prolong the debate as part of the maintenance discourse. Treating marriage as a contract does little more than trigger the more critical issue of whether good faith and fair dealing require maintenance in a given case. A richer model is needed to identify more precisely the circumstances in which maintenance is appropriate and to quantify the amount of a maintenance order. The contemporary law of partnership provides such a model.

\section{B. A Contemporary Model-The Maturing of Partnership Marriage}

1. An analogy-Concept, fact, and law.

A partnership model for marriage has great conceptual appeal. The "ideal to which marriage aspires [is] that of equal partnerships between spouses who share resources, responsibilities, and risks" and thus perhaps some limited duty to sacrifice for the good of the partnership. ${ }^{238}$ This norm encourages commitments between spouses, promotes gender equality, and supports caretaking of children and elderly dependents. ${ }^{239}$ Indeed, much of the contemporary writing on divorce reform espouses such an ideal relationship, even when the writer declines to endorse the partnership metaphor. The most powerful support for a partnership model thus lies in its egalitarian framework.

In addition to its normative appeal, support for a partnership model can be drawn from the many de facto similarities between a marriage and a handshake partnership. Both relationships typically commence with the exchange of commitments and without express agreement or advice of counsel. ${ }^{240}$ Both relationships seek profits, though profit in the case of marriage may be emotional,

\footnotetext{
${ }^{2 s 8}$ Deborah L. Rhode and Martha Minow, Reforming the Questions, Questioning the Reforms, in Divorce Reform 191, 199 (cited in note 41).

${ }^{239}$ See id. Professors Rhode and Minow argue that protection for such sharing behavior is critical in view of the lack of adequate child care and parental leave policies, flexible scheduling, or significant part-time work. Id.

${ }^{240}$ See Alfred F. Conard, Robert L. Knauss, and Stanley Siegel, Agency, Associations, Employment and Partnerships 18 (Foundation, 4th ed 1987) ("The great mass of ordinary
} 
sexual, and perhaps spiritual as well as financial. ${ }^{241}$ Both often involve a specialization of labor. Commonly, one partner contributes capital primarily or exclusively, while another contributes services primarily or exclusively ${ }^{242}$ - a specialization that resembles a traditional marriage, as well as many contemporary ones, in which the husband contributes income through outside employment and the wife contributes caretaking services. ${ }^{243}$

Additional support for a partnership analogy lies in the law governing partnerships, the Uniform Partnership Act ("UPA"). The UPA codifies the law of partnership in forty-nine states. ${ }^{24}$ While the UPA acknowledges the consensual nature of a partnership and generally defers to party autonomy, it contains several mandatory provisions. These provisions are as essential to a marriage as to a purely commercial relationship. For example, the UPA recognizes a broad fiduciary duty among partners, ${ }^{245}$ a duty consistent with the social norm of reciprocal trust and love between spouses. In another mandatory provision, the UPA recog-

partnerships are probably in that form because the parties never gave their organizational structure much thought. Their agreements are informal, and often unwritten.").

${ }^{241}$ The UPA $\$ 6,6$ ULA 22 (West 1969) defines partnership as "an association of two or more persons to carry on as co-owners a business for profit." According to UPA § 7(4), 6 ULA 39 (West 1969), evidence that a person shares profits is "prima facie evidence that he is a partner."

The factors that induce formation of partnerships are cogently discussed in Conard, Knauss and Siegel, Agency at 17 (cited in note 240). These factors provide an interesting commentary on contemporary marriage:

One of the outstanding features of the organizational revolution is the impulse of people to join in common endeavors. This impulse is commonly attributed to the desire to pool money, resources, skills, and intelligence for greater achievements; it may also respond to some less rational need for affiliation or psychic reinforcement. Modern laws generously provide convenient receptacles for these efforts, by way of corporations for business, religious, eleemosynary, educational or social purposes. However, millions of people continue to pool their resources through less formal, or substantially unstrucId. tured groups. Of these, the best known to the law is the ordinary partnership.

${ }^{242}$ See Robert W. Hamilton, Fundamentals of Modern Business $\$ 13.3 .4$ at 306 (Little, Brown, 1989).

${ }^{243}$ This specialization may produce consequences in marriage, however, that differ from those produced in a commercial partnership. If property is minimal, a homemaker who has primarily contributed services to the marriage may suffer a loss resulting from her participation if the relationship ends-a consequence that is not as likely to result from serviceparticipation in a purely commercial partnership.

244 See Hamilton, Fundamentals $\S 13.3 .1$ at 304 (cited in note 242).

${ }^{245}$ See id. In this regard, the influence of relational contract theory is apparent. See note 220 and accompanying text. Under current drafts of the Revised Uniform Partnership Act ("RUPA"), however, this fiduciary duty is a default rule rather than a mandatory one. 
nizes the broad authority of partners to bind the partnership; ${ }^{246}$ this rule recalls the common law duty to support a spouse, which empowered a spouse to bind a mate to repay the merchant who supplies necessaries. ${ }^{247}$ Also, the UPA recognizes the unalterable right of a partner to dissolve the partnership at any time, notwithstanding even the most explicit agreement to the contrary. ${ }^{248}$ Such a right is the linchpin of no-fault divorce, which authorizes divorce at the will of either party, upon a finding that the marriage is "irretrievably broken." 249

In addition to its mandatory provisions, the UPA contains an array of default rules that are triggered by the frequent failure of commercial partners, like spouses, to negotiate the terms of their relationship. ${ }^{250}$ For example, one default provision makes partners co-owners rather than individual owners of partnership property, ${ }^{251}$ a view that mirrors the rule in many marital property statutes that property acquired during marriage is presumed to be

${ }^{266}$ Id. UPA $\S 9(1), 6$ ULA 132 (West 1969), recognizes the general ability of a partner to bind the partnership through acts "for the purpose of its business."

${ }^{247}$ See Clark, 2 Domestic Relations at 423-24 (cited in note 32).

248 UPA $\$ \$ 29,31,6$ ULA 364, 376 (West 1969). See Conard, Knauss, and Siegel, Agency at 434 (cited in note 240) ("One of the most salient characteristics of a partnership is its impermanence-its terminability."). For a general discussion of dissolution and termination, see Harold Gill Reuschlein and William A. Gregory, The Law of Agency and Partnership $\$ \S 227-42$ (West, $2 d$ ed 1990). See also Donald J. Weidner, Three Policy Decisions Animate Revision of the Uniform Partnership Act, 46 Bus Law 427, 435-38 (1991) (analyzing confusion surrounding issue of dissolution).

240 See UMDA § 302(a), 9A ULA 181 (West 1987), which requires a court to enter a decree of dissolution of marriage if:

(2) the court finds the marriage is irretrievably broken, if the finding is supported by evidence that (i) the parties have lived separate and apart for a period of more than 180 days next preceding the commencement of the proceeding, or (ii) there is serious marital discord adversely affecting the attitude of one or both of the parties toward the marriage ....

In a few states, however, no-fault divorce is available only by mutual consent. Kay, $56 \mathrm{U}$ Cin L Rev at 5-6 \& n 20 (cited in note 41).

${ }^{230}$ For a discussion of the reasons business persons and spouses often fail to negotiate the terms of their relationship, see note 226. Under partnership law, various agreements between partners may be made without any paper record and established through later testimony. See Balafas $v$ Balafas, 263 Minn 267, 117 NW2d 20, 24-25 (1962). In the case of marriage, the possibility that a spouse might attempt fraudulently to establish an oral agreement denying or limiting a buyout right raises legitimate concern. One possible answer to this concern would be to impose a writing requirement on such an agreement. See, for example, Uniform Marital Property Act $\$ 10(a), 9 A$ ULA (West 1987).

${ }_{251}$ See UPA § 25(1)-(2), 6 ULA 326 (West 1969). See also Weidner, 46 Bus Law at 430 (cited in note 248) (describing shift away from tenancy model of co-ownership in a partnership). 
marital property. ${ }^{262}$ The UPA default rules further provide that "[a]ll partners have equal rights in the management and conduct of the partnership business," vided equally. ${ }^{254}$ These concepts are consistent both with modern equality rhetoric concerning conduct within marriage and with community property statutes, ${ }^{255}$ though perhaps they are not yet actualized in all homes. ${ }^{256}$

The UPA default rules governing the dissolution of a partnership are especially relevant. Indeed, this aspect of partnership law seems to have inspired the UMDA to adopt a partnership model for divorce. ${ }^{257}$ The UPA provides that a partnership dissolves upon the at-will departure of a partner. ${ }^{268}$ Partners who have not dissolved wrongfully have a right to wind-up; other partners can seek a judicial wind-up. ${ }^{259}$ Winding-up includes the completion of unfinished partnership business, liquidation of assets, payment of debts, and distribution of any remaining proceeds to the partners ${ }^{260}$ - a process analogous to the final settlement of property rights on divorce. As part of this process, each partner's capital contribution is returned. ${ }^{261}$ This rule resembles many equitable distribution statutes that require return of spouses' separate prop-

${ }^{202}$ See generally Clark, -2 Domestic Relations at 183-90 (cited in note 32 ). This presumption may be rebutted by showing that the property falls within one of the exceptions to the general rule and is therefore separate property. Separate property includes property acquired prior to marriage, or acquired during marriage by gift, bequest, devise, or inheritance. Id at 184, 186.

${ }^{253}$ See UPA $\S 18(e), 6$ ULA 213 (West 1969). Accord RUPA § 401(f) (October, 1992 draft).

${ }^{254}$ UPA § 18(a), 6 ULA 213 (West 1969). See Conard, Knauss, and Siegel, Agency at 391 (cited in note 240 ).

${ }^{2 s 5}$ Community property states make spouses co-managers of community property. See, for example, Cal Civ Code $§ 5125$ (West Supp 1992).

${ }^{256}$ Dean Prager notes that it is common practice for spouses to pool property with control in one or both spouses. Prager, Shifting Perspectives at 120 (cited in note 43). The tendency to pool property tends to increase as family income decreases. Id at $129 \mathrm{n} 21$.

287 See text accompanying notes $33-46$.

${ }^{288}$ See UPA $\S \S 31,32,6$ ULA 376, 394 (West 1969).

${ }^{259}$ See UPA $\S \S 37,38(1), 6$ ULA 444, 456 (West 1969). See also UPA § 30, 6 ULA 367 (West 1969), which distinguishes between a dissolution and a winding up: "On dissolution the partnership is not terminated but continues until the winding up of partnership affairs is completed." See Official Comment to UPA § 29, 6 ULA 365 (West 1969) defining "winding up" as the "process of settling partnership affairs after dissolution."

${ }^{260}$ See Reuschlein and Gregory, Law of Agency at 345 (cited in note 248).

${ }^{261}$ UPA \& 40, 6 ULA 468-69 (West 1969), details the rules for distribution of partnership property. Essentially, that section requires distributions to (1) creditors; (2) partners for loans to the partnership; (3) partners in respect of capital; and (4) partners in respect of profits. See Alan R. Bromberg and Larry E. Ribstein, Bromberg and Ribstein on Partnership \$ 7.10 at 7:92 (Little, Brown, 1991). See also Reuschlein and Gregory, Law of Agency $\S \S 228,238$ (cited in note 248). 
erty prior to the distribution of marital property. ${ }^{262}$ Winding-up terminates the partners' mutual rights and obligations. ${ }^{263}$ This consequence underscores the clean-break notion of no-fault divorce statutes; the distribution of marital property marks an end to the parties' financial entanglement, thus affording each spouse a fresh start.

In practice, however, partnership business typically is not wound-up, but continues after dissolution, sometimes by a new partnership that rises from the ashes of the first. ${ }^{264}$ In a fixed-term partnership, remaining partners may elect to continue the business for the agreed term, provided they pay to the retiring or wrongfully-departing partner the value of her interest in the partnership. ${ }^{265}$ This buyout right of the departing partner is usually more valuable than the right to wind-up, because it can be realized much more quickly and it avoids judicial reluctance to extinguish the remaining partners' means of livelihood.

Recent drafts of the Revised Uniform Partnership Act ("RUPA") $)^{286}$ preserve the rule that a partner can leave the partnership at any time, ${ }^{267}$ but expand and detail the right of a departing partner to force a buyout rather than a winding-up. ${ }^{268}$ Such a

${ }^{262}$ See, for example, UMDA § 307, 9A ULA 238-39 (West 1987). Alternative A, designed for common law states, authorizes the equitable distribution of "property and assets belonging to either or both however and whenever acquired." Id at 238. Alternative A further provides, however, that one factor to be considered in the distribution of such property is the "contribution ... of each party in the acquisition" of property. Id at 239. Alternative $B$, designed for community property states, clearly authorizes the return of "each spouse's separate property" before community property is divided. Id.

${ }^{203}$ See Bromberg and Ribstein, Partnership $\S 7.08$ (cited in note 261). The parties' mutual rights and obligations are thus not terminated by the dissolution but continue until the winding up is completed, UPA $\S 30,6$ ULA 367 (West 1969), which occurs when every obligation has been discharged by performance.

284 See Donald J. Weidner, The Revised Uniform Partnership Act Midstream: Major Policy Decisions, 21 U Toledo L Rev 825, 837 (1990).

2os The UPA specifically authorizes continuation of partnership business when a partner wrongfully dissolves a partnership before expiration of a fixed term. UPA $\S 38(b), 6$ ULA 456 (West 1969). The amount paid a wrongfully-departing partner may be offset by damages caused by the wrongful departure and does not include the value of goodwill in the business. Id. See also UPA § 42, 6 ULA 521 (West 1969) (rights of retiring partner or estate of deceased partner when the business is continued).

280 See note 230 for a discussion of the origin of the RUPA. Cites to the RUPA refer to the October 28, 1992 text (without comments) and the comments to the August 1991 draft.

${ }^{267}$ See Comment to RUPA \& 601 (August 1991 draft); RUPA § 601(1) (October 1992 draft).

188 RUPA § 801 states that a partnership dissolves and its business must be wound up only upon the occurrence of listed events, suggesting a starting point of continuation, rather than dissolution as under the UPA. The RUPA attempts to clarify this new rule by distinguishing between a "dissociation" (the departure of a partner) and a "dissolution" (the winding up of its business and termination of a partnership). In Article 7, the RUPA details 
buyout commonly occurs when a partner dissociates before the expiration of a definite term, in which case partnership business may continue. ${ }^{268}$ If the business continues, the RUPA requires a buyout of the dissociated partner's interest $t^{270}$ and identifies the method for calculating the buyout price. ${ }^{271}$

\section{An application-Dissociation and buyout.}

The UPA buyout rules and their expansion in the RUPA provide a useful analogy for the modern marital relationship. Contemporary marriage is a partnership for a term (the life of one partner), ${ }^{272}$ although spouses, like commercial partners, have the power to leave the relationship at any time. A spouse's decision to end the relationship results in her dissociation, but does not necessarily trigger a winding-up of any shared enterprise in which the spouses have invested. If this enterprise continues, a dissociated spouse should receive a buyout of her investment.

the effects of dissociation; in Article 8, it details the effects of dissolution. See also RUPA \& 801, comment (August 1991 draft).

${ }^{269}$ When the partnership is for a definite term, a partner's wrongful dissociation dissolves the partnership only upon "receipt by the partnership of notice from another partner of that partner's express will to withdraw as a partner." RUPA § 801(2)(i). The RUPA thus makes an important shift away from a rule of dissolution upon departure of a partner before expiration of a term to a rule of dissolution only upon additional specified events.

${ }^{270}$ RUPA \& 701(a).

271 RUPA \& 701(b) states:

The buyout price of a dissociated partner's interest is the amount that would have been distributable to the dissociating partner .... if on the date of dissociation, the assets of the partnership were sold at a price equal to the greater of liquidation value or the value based on a sale of the entire business as a going concern without the dissociated partner and the partnership were wound up as of that date. In either case, the selling price of the partnership assets must be determined on the basis of the amount that would be paid by a willing buyer to a willing seller, neither being under any compulsion to buy or sell, and with knowledge of all relevant facts. Interest must be paid from the date of dissociation to the date of payment.

This buyout price must, however, be offset by any damages for wrongful dissociation. RUPA $\S 701$ (c). Wrongful dissociation usually occurs when a partner leaves the partnership before expiration of a definite term. RUPA $\S 602(a)(2)(i)$. Premature departure is also wrongful if a partner is expelled by judicial decree upon a determination that "the partner engaged in conduct relating to the partnership business which makes it not reasonably practicable to carry on the business in partnership with the partner." RUPA $\S \S 602(a)(2)(i i), 601(5)$. See also UPA \& 32 (1)(d), 6 ULA 394 (West 1969).

${ }^{272}$ The traditional vow- "until death do us part"-defines this term. Even under nofault, traditional marriage is not, of course, like the classical at-will relationship (which is actually not a contract). In the paradigmatic at-will relationship, an employment arrangement, either the employer or the employee may terminate the relationship at will, with no further financial consequences. Such an arrangement more closely resembles cohabitation than marriage. 
This reasoning raises some immediate conceptual concerns. In the case of marriage, who should buy out whom-that is, which spouse is the dissociated spouse? Even more fundamentally, is there a shared enterprise that continues after divorce, thus requiring the spouse who continues it to buy out the interest of the dissociated spouse? The answers to these questions draw heavily on human capital theory. ${ }^{273}$

Human capital theorists stress the investment of the marital unit in the human capital of a spouse who undertakes professional education or training to increase future productivity. ${ }^{274}$ While human capital theory generally focuses on cases of educational investment, a broader view of marital investment is possible. ${ }^{275}$ An investment in human capital may occur simply through the expenditure of time and effort in the job market, which results in experience and perhaps seniority. When, for example, a husband works outside the home and a wife works exclusively in the home, the marital unit makes an investment in the husband's human capital just as surely as when the husband enters college. The parties expect that this joint investment will generate a return that will be jointly enjoyed. Although dissociation terminates the parties' relationship, it usually does not terminate this income-generating marital enterprise-which continues to function in the marketplace, exclusively or primarily in the hands of the husband. In such cases, the wife who has dissociated from this marital enterprise should receive a buyout of her interest. The implications of this principle are best explained by reference to three paradigmatic marriages: (1) the traditional marriage, (2) the hybrid marriage, and (3) the egalitarian marriage.

If the spouses opt for a traditional marriage in which the husband works outside the home and the wife is a full-time homemaker, ${ }^{276}$ the marital unit has invested exclusively in the husband's human capital. ${ }^{277}$ When the parties divorce, the husband leaves the

273 See text accompanying notes 211-18.

274 See text accompanying note 213 .

${ }^{275}$ See note 218 and accompanying text.

276 A large number of couples still choose this option. The Bureau of Labor Statistics reported that in 1991, approximately 16 million married women did not participate in the labor force because they were "keeping house." Bureau of Labor Statistics at 26 (cited in note 3).

277 While this traditional wife presumably is gradually enhancing her domestic skills through experience, these skills have little marketable value, and in fact they may decline in value through use (that is, as a woman ages, and thereby becomes less marriageable). See Ellman, 77 Cal L Rev at $43-44$ (cited in note 54) (citing statistics demonstrating that a woman's marriageability diminishes with age more quickly than a man's). 
marriage with enhanced earning capacity, which is the product of a marital investment in his human capital. ${ }^{278} \mathrm{He}$ thus takes the marital enterprise with him. When these traditional spouses divorce, the wife should receive a buyout of her interest in this continuing marital enterprise.

In a hybrid marriage, perhaps the most common of the three paradigms, the wife assumes most of the homemaking and childcare responsibilities, and also works outside the home, either parttime, part-year, or full-time, often in the secondary job market. Because of these multiple responsibilities, this wife has fewer hours to devote to her employment than does her husband. ${ }^{279}$ Consequently, her career opportunities and advancement may be limited, resulting in income disparity between husband and wife. In this hybrid marriage, the marital unit invests primarily in the husband's human capital and secondarily in the wife's human capital. When the wife dissociates from the marriage, she takes with her a part of the marital enterprise, measured by her own enhanced earnings attributable to marital investment. If she takes a smaller portion of the marital enterprise than her spouse takes-i.e., if her enhanced earnings are less than his-she should receive a buyout.

In an egalitarian marriage, both spouses work full-time and each performs fifty percent of the household chores and childcare. In such an extraordinary relationship, ${ }^{280}$ the marital unit makes two equal investments-one in the human capital of the husband and another in the human capital of the wife. ${ }^{281}$ It might therefore

${ }^{278}$ In each of the three paradigmatic marriages discussed herein, the spouses' enhanced earnings at the time of dissociation are assumed to be a rough estimate of the value of the marital enterprise. In the ordinary case, such enhanced earnings are measured by calculating the difference between income at the time of marriage (in present dollars) and income at the time of dissociation. In certain extraordinary cases, such as when a professional degree was obtained immediately before marriage or immediately before divorce, a more sophisticated measure may be required. A formula for measuring enhanced earnings is presented in Part IV of this Article.

${ }^{279}$ As Dean Prager explains, even when neither spouse forgoes employment to care for children, "at least one partner must stand ready in emergencies and be flexible enough to reclaim children when child care arrangements end .... Both are not free to travel on business; both are not necessarily available for overtime or flexible hours. Although some may truly try to share responsibilities for children, many will conclude that it is more functional for one of them to do so." Prager, Shifting Perspectives at 119 (cited in note 43). It would be naive to assume that the spouse who undertakes such child care responsibilities can devote as much time and attention to her career as her spouse.

${ }^{280}$ A truly egalitarian relationship may be unusual. See note 11 and accompanying text (suggesting that even when women work full-time they usually undertake a disproportionately large share of household responsibilities).

${ }^{281}$ One factor that suggests these investments are equal is their equal cost to the marital unit-each spouse devotes roughly equal numbers of hours to outside/non-marital tasks. 
appear that, because the egalitarian marital unit has invested equally in the spouses, each spouse should take one-half of the marital enterprise upon divorce and neither should receive a buyout.

This reasoning, however, oversimplifies the issue. Valuation of a continuing enterprise is not based on the size of various investments, but rather on the returns on those investments. ${ }^{282}$ In marriage, as in a commercial partnership, one investment may generate more income than another. Whatever the reason for this differential, the resulting loss or gain is borne by the partnership and not by the partners individually. When a wife dissociates from an egalitarian marriage, she should receive a buyout if her enhanced earnings are less than those of her husband.

As a practical matter, if no buyout were required upon dissociation from an egalitarian marriage, the divorce proceeding could easily degenerate into a debate over whether a wife performed fifty percent or only forty-nine percent of caretaking responsibilities. A husband, for example, who could prove that he matched the nine hours each week his wife spent transporting children, the seven hours she spent preparing meals, the 4.2 hours she spent cleaning house, and the 5 hours she spent laundering clothes, etc. (and that he had done so for the duration of the marriage) could avoid paying his wife a buyout no matter how disparate their enhanced earnings. Divorce would thus raise a series of unanswerable questions: Does ten hours of vacuuming equal ten hours of watching a little league baseball game? Ten hours of cleaning bathrooms? Ten hours of helping children with homework? Ten hours of painting a bedroom? And what of the husband who was a more efficient grocery shopper than his wife, or the wife who more efficiently vacuumed the house? Such a focus is ludicrous and inappropriate. The real issue is not the identity of contribution, but the return to the marital unit on joint investments.

3. A prediction-Ex ante effects.

Any proposal for legal reform should be tested for its ex ante as well as its ex post impact. Thus, a law of divorce that would

\footnotetext{
Even where hours on the job equate, however, costs may differ. Consider, for example, a case in which one spouse's job is more stressful than the other's, requiring a greater personal investment that negatively impacts the marital unit by making that spouse less pleasant at home.

${ }^{282}$ See Parkman, 40 Ark $L$ Rev at 442 (cited in note 211) ("The value of the investment is not the expense incurred, but the returns generated.").
} 
require a buyout must be tested for its impact on ongoing marriages.

a) Immediate effects. Modeling divorce after contemporary partnership law probably will have minimal, if any, immediate effect on the roles of spouses in ongoing marriages. The traditional homemaker/breadwinner dichotomy is deeply embedded in American culture and has been largely unresponsive to changes in divorce law. No-fault reforms, for example, have not persuaded most women to abandon primary caretaking responsibilities, despite evidence that no-fault increases both the likelihood of divorce and the likelihood that a divorcing caretaker will suffer a financial catastrophe. $^{283}$

At times, necessity combines with the sex/gender system to make a woman's role as homemaker virtually inescapable. For example, the inadequacy of the American day-care system, for both children and the aging, often necessitates that a family member limit occupational choice and advancement in order to care for these individuals. ${ }^{284}$ The sex/gender system usually ensures that the wife fills the gap. Divorce law reform probably will not deter these women from assuming a caretaking role.

A contemporary partnership model will, however, curtail a husband's current opportunity to benefit from the birth and nurturance of children and then deny his wife her expected share in enhanced earnings. ${ }^{285}$ Divorce reform may also ameliorate the distorting effect created by divorce distribution law, which refuses to include enhanced earnings within the definition of property, thus providing an inefficiently strong incentive for a husband to invest in just those non-distributable assets.

Divorce reform might also, in some cases, encourage the use of prenuptial agreements. A man aware of buyout rules, for example, might insist upon a prenuptial agreement before marrying a home-

\footnotetext{
${ }^{283}$ See text accompanying notes $46-80$ (chronicling the financial plight of homemakers under no-fault). See also notes 3-13 and accompanying text.

284 "National policy toward childcare has been notable largely for its absence." Rhode, Justice and Gender at 129 (cited in note 11). Professor Rhode cites national surveys indicating that between one-quarter and one-third of interviewed mothers express dissatisfaction with their child care arrangements or cite inadequate child care as a major barrier to employment. Id at 130 .

${ }^{285}$ See Ellman, $77 \mathrm{Cal} \mathrm{L} \mathrm{Rev} \mathrm{at} 41-43$ (cited in note 54) (observing that a husband reaps the financial benefits of marriage early in the relationship when children are born and nurtured, while a wife reaps those benefits much later when her husband's earning capacity peaks).
} 
maker. ${ }^{286}$ The underutilization of prenuptial agreements today may be partly a function of the fact that most men are adequately protected by no-fault divorce laws and thus do not need them. If women are culturally encouraged to adopt a more passive posture than men, as some commentators have suggested, ${ }^{\mathbf{2 8 7}}$ one might suppose that women are less inclined than men to seek contractual protection of their interests. If the tables were turned so that men generally perceived a financial incentive to enter prenuptial agreements, the number of such agreements might increase. This possibility suggests the need for expanded efforts to protect wives who are culturally disadvantaged in negotiations with men, a task best left to subsequent discourse.

b) Long-term effects. Protecting caretakers today exacts no future toll. To the contrary, a contemporary partnership model supposes and encourages positive concepts of marital sharing, equality of right and responsibility, and thus more fluid roles between the sexes. Moreover, a gradual relaxation of the sex/gender system in the home ultimately may be duplicated in the marketplace, which has long reflected and exacerbated that system. To the extent, for example, that a wife and husband share caretaking responsibilities, the wife can increase her attachment to the marketplace and thus possibly her choices and opportunities for advancement. Ultimately, equalizing the employment investments of women and men may erode the stereotyped division of labor in the marketplace.

Such visions, however, may be only wishful thinking. Perhaps a contemporary partnership model for marriage will have no effect whatsoever on the long-entrenched sex/gender system in either the private or the public sphere. But perhaps it is more than enough to hope that such a model will halt the financial exploitation of caretakers under no-fault.

286 While it is also possible that a man might be dissuaded from marrying a homemaker, this result is less likely since the decision to marry is often a romantic rather than a pragmatic one. This man could, of course, attempt to protect himself by encouraging his spouse to work outside the home.

287 An implicit criticism of prenuptial agreements has been lodged by commentators who question the ability of women in general to bargain with men in view of cultural factors that encourage a conciliatory posture in women and an aggressive posture in men. See Mary Pat Treuthart and Laurie Woods, Mediation-A Guide for Advocates and Attorneys Representing Battered Women 13-14, 75 (1990). Premarital agreements have also been criticized in view of the fluctuating nature of the marital relationship and the failure of many spouses to amend their contracts to reflect shifting attitudes. See Prager, Shifting Perspectives at 123 (cited in note 43). 


\section{Proposal for Legislative Reform}

Simple justice requires that a dissociated homemaker receive a buyout of her interest in any continuing marital enterprise. Legislation can ensure this buyout most expediently by providing more precise rules and more predictable results than those obtainable through judicial reform. This legislation should establish brightline rules that include a presumptive method for calculating a buyout and limit trial court discretion to apply those rules in a gender-biased fashion. ${ }^{288}$

\section{A. Maintenance as Buyout}

As previously explained, the right to a buyout depends upon identifying a marital enterprise that continues after dissociation. ${ }^{\mathbf{2 8 9}}$ Such an enterprise continues when either or both spouses generate post-divorce income that is attributable to marital investments. While the concept of dissociation from an ongoing enterprise can identify cases in which a buyout is appropriate, it does not quantify the appropriate amount of a buyout. A wide array of formulae are possible to fix this amount. ${ }^{290} \mathrm{I}$ offer a model based on a simple

\footnotetext{
${ }^{288}$ Valuation on a case-by-case basis could be an expensive task. Professor O'Connell criticizes human capital theory on the ground that quantification "will require expensive expert testimony, a cost which even upper-middle-class wives find difficult to underwrite." O'Connell, 23 New England L Rev at 503 (cited in note 31).

${ }^{289}$ See text accompanying notes $264-82$. The buyout right should not depend, of course, on which spouse seeks dissociation if the spirit of no-fault is to be preserved. The question of whether a buyout should be denied a spouse guilty of marital fault is beyond the scope of this Article, though one might reasonably suppose that an investment over time in the human capital of a spouse would occur regardless of that spouse's marital fidelity or infidelity. Some states, however, deny maintenance to a "guilty" spouse. See Freed and Walker, 24 Family L Q at 355-56 (cited in note 110).

${ }^{290}$ A buyout could be measured by the cost of the investment in human capital, such as sums actually contributed to tuition and the lost opportunities of the contributing spouse. See Combs, 2 J Divorce at 341-54 (cited in note 211) (suggesting measurement of both lost opportunities and amount of investment). Such a method of measurement, which focuses on reliance rather than expectation, is troublesome on several counts. First, in many cases, the actual funds contributed to a spouse's education may be insignificant when compared to the return realized on this investment, and thus may seriously undercompensate a dissociated spouse. Second, if contributions include homemaking services, difficult valuation problems arise in the effort to put a market price tag on such personal services as chauffeuring children to school events, attending school meetings, and providing emotional and spiritual support and security. Third, measurement based on lost opportunity is troublesome because it entails a dubious inquiry into "what-ifs" and an equally dubious focus on a spouse as victim rather than investor. See text accompanying note 210. Finally, a focus on the wife's "sacrifice" is inconsistent with the parties' expectations. The family decision to invest primarily or exclusively in the husband's human capital, for example, was likely made with the expectation that the family would enjoy a return on that investment. If the marriage contract ends
} 
mathematical calculation of enhanced earnings. This model is not intended as a fait accompli, but rather as a springboard to discussion and, I hope, to much-needed legislative reform.

\section{B. An Enhanced Earnings Model}

The proposed model values a continuing marital enterprise by measuring the spouses' enhanced ability to generate income. ${ }^{291}$ In drafting this model, I have opted for simplicity and the limitation of variables whenever possible to provide a framework that maximizes predictability and minimizes costs for the parties.

\section{Valuing the enterprise.}

The value of a continuing marital enterprise should be fixed at the time of dissociation. This valuation will define all the parties' rights and obligations, thus providing the psychological and financial-planning benefits of a clean break. ${ }^{292}$

Recent drafts of the RUPA suggest that a continuing business should be valued by measuring "the greater of liquidation value or value based on a sale of the entire business as a going concern without the dissociated partner."293 Liquidation value is the amount of revenue partnership assets would generate at a fire sale-that is, if the business were closed down and its assets sold. In the case of marriage, liquidation value would measure the value of traditional marital property, which is ordinarily distributed as part of the property award. Such property might include automobiles, bank accounts, jewelry, and equity in the marital home. Often, it is a small sum. ${ }^{294}$

Liquidation value, however, is an unsatisfactory measure of the value of a business where liquidation is not contemplated, because value in such cases consists in the ability to generate income rather than the value of liquidated assets. Liquidation value is therefore an unsatisfactory measure of the value of a continuing marital enterprise, which lies in human capital rather than liquidatible assets. Thus, the best method for valuing a marital enterprise measures its value as a going concern. This process requires two

prematurely, the wife should receive the benefit of the bargain, which is a share of the husband's enhanced earnings, not compensation for the depreciation of her own human capital.

291 This model builds on the work of other human capital theorists. See note 211 .

${ }^{292}$ See RUPA $\S 701(b)$ (determining buyout price as of time of event causing dissociation).

293 Id.

29 See text accompanying notes 85-107. 
steps: (1) estimating the parties' future earnings, and (2) measuring enhancement, the part of those future earnings attributable to marital investments.

a) Estimating future earnings. One well-established method for estimating a future stream of earnings simply averages net income over a prior period: for example, over five consecutive years. $^{295}$ Although a more sophisticated estimate is possible, ${ }^{296}$ averaging would provide a simple and inexpensive estimate of income in the ordinary case. ${ }^{297}$

The extraordinary case could be addressed by creating a legislative presumption favoring estimation through averaging, thus placing the burden on a spouse disputing this measure to offer a more accurate estimate. An extraordinary case might arise, for example, if a spouse pursued a professional degree during the marriage and obtained that degree immediately before dissociation, so that enhanced income had not yet been recognized from what was clearly a marital investment. In such a case, future earnings might have to be based on the average earnings of other persons with similar degrees. ${ }^{298}$

Future earnings would thus presumptively be measured at the time of dissociation using the following formula:

For each spouse,

$$
\mathrm{EAD}=\text { Estimated Earnings At Dissociation }
$$

${ }^{295}$ See Hamilton, Fundamentals $\S 11.5 .1$ at 235-37 (cited in note 242). Fringe benefits, such as health insurance, probably should be included in income. While inclusion of these benefits might make the valuation process more difficult, their exclusion would tend to produce a distorted estimate of actual income.

${ }^{296}$ Future payments might also be estimated by more heavily weighting the most current years. See Burke and Rosen, Valuing Educational Attainment at 66 (cited in note 98). Alternatively, payments might be estimated by using a "decision tree," in which probabilities are assigned to likely cash-flow outcomes and all possible results are weighted. See Hamilton, Fundamentals $\S 11.5 .1$ at 237 (cited in note 242).

292 Prior income could easily be established through old tax returns, which can be obtained by using IRS Form 4506. In the case of a self-employed person whose tax return suggests negative income, further inquiry might be appropriate to evaluate actual cash flow from the business by taking into account nonbusiness and noncash expenses such as depreciation.

${ }^{208}$ This was, in fact, what occurred in O'Brien, where the trial court estimated future earnings based on the income of an average surgeon. $489 \mathrm{NE} 2 \mathrm{~d}$ at 714. See also Combs, $2 \mathrm{~J}$ Divorce at 345-46 (cited in note 211) (suggesting this method of estimation for marriages of short duration); and Renick, Spousal Contribution to a Professional Degree Upon Divorce at 63-65 (cited in note 97). The speculative nature of this valuation suggests that the buyout order should be modifiable upon a showing of changed circumstances. See text accompanying notes 311-14. 
(average annual net income ${ }^{299}$ for the shorter of (1) five consecutive one-year periods prior to dissociation or (2) each year of marriage)

Once future earnings are estimated, this figure must be reduced to reflect only those earnings attributable to marital investment.

b) Measuring enhancement. A buyout is not a windfall for the spouse who catches a rich mate. Rather, it is a return on an investment. Thus, the value of the marital enterprise should reflect only the enhancement in human capital that results from marital investment..$^{300}$ Especially where the spouses marry later in life, possibly not for the first time, it is important to establish the date of marriage as a baseline. Although it is not possible to measure enhancement with absolute precision, enhanced earnings could be estimated using the following formula:

For each spouse,

EAM $=$ Estimated Earnings At Marriage (current dollars) ${ }^{301}$

\footnotetext{
299 Federal, state, and local taxes and social security taxes, which are nondiscretionary income, should be deducted from gross income to calculate net income.

soo Native talent, personal ambition, and circumstance may, of course, greatly impact enhancement. A husband's success as a rocket scientist, for example, may stem largely from his genius; a wife's more limited success as a corporate executive may stem largely from discrimination against women within her organization. These realities, however, do not establish that enhanced earnings do not flow from marital investment. Rather, they merely define the qualities and life circumstances of the person in whom the investment is made.

It is, however, somewhat of a fiction to say that an enhancement in human capital during marriage is strictly a product of investments made during the marriage. Investments in human capital occur over a lifetime, and it may well be that an investment made very early in life and well before marriage will not yield a return until sometime during marriage. See Parkman, 40 Ark L Rev at 446 (cited in note 211). Professor Parkman's solution to this problem is to treat human capital as marital property only when the investment during marriage is "substantial," and only when the investment would not have occurred without the support of the spouse. Id at $448,460,465$.

To take an easy example, a largely pre-marital investment yields a return during marriage when a woman marries a student in his last year of medical training. If this couple divorces after the husband's first year of medical practice, the wife might claim a huge buyout based on her husband's enhancement in human capital that occurred during marriage but that is largely attributable to a pre-marital investment. This situation could be easily addressed, however, by adopting a sliding scale buyout share based on the length of the marriage. If the marriage lasted only one year, for example, the wife might claim only $3 \%$ of her husband's enhanced earnings. See note 309 and accompanying text. This solution would address the problem without requiring a difficult and speculative inquiry into the likelihood that the husband would have made the same investment had the parties not married.

sor Payments at marriage should be measured in dollars at the time of dissociation. This could easily be done by reference to the Consumer Price Index. See Combs, $2 \mathrm{~J}$ Divorce at 345 (cited in note 211).
} 
(average annual net income for the shorter of (1) five consecutive one-year periods prior to marriage or (2) each year of employment prior to marriage $)^{302}$

$$
\mathrm{EAD}-\mathrm{EAM}=\mathrm{E} \text { (annual enhanced earnings) }
$$

This formula will produce an estimate of the annual earnings after dissociation attributable to investments made during marriage. ${ }^{303}$ The spouses' combined ability to generate enhanced earnings constitutes the value of the marital enterprise. This value could be reduced to a lump sum at the time of dissociation by: (1) fixing the number of periods over which enhanced earnings are measured, ${ }^{304}(2)$ multiplying this number of periods by annual en-

Using the date of marriage as a baseline, however, may encourage marriages post-graduation because, at least from a financial perspective, it would verge on the irrational for a student to marry a year or two short of graduation. While it is true that this baseline might discourage marriage by a student, an earlier, pre-marital baseline would be subject to the conceptual objection that it gives a spouse a return not traceable to a marital investment. The concerned student could, of course, protect his financial interests by entering a prenuptial agreement.

${ }^{302}$ If a spouse was not employed at any time during the five years before marriage, income could be attributed to that spouse by using the figure for minimum wage, full-time employment at the time. If a spouse worked only part-time before marriage, annual income would be full-time employment at the same rate. Alternatively, wages for an unemployed or underemployed spouse might be estimated through expert evaluation of the wages that could have been earned if that spouse had worked full-time.

Elizabeth Beninger and Jeanne Smith suggest the latter approach. See Beninger and Smith, 16 Family L Q at 215 (cited in note 211). But the added cost and decreased predictability that such a method would generate suggest that its use should be limited. This limitation could be effected by creating a rebuttable presumption that full-time minimum wage income should be attributed to a spouse who was unemployed for the five years preceding the marriage. The spouse dissatisfied with this measure would have an opportunity to establish a better estimate.

sos This formula will not, however, measure enhancements in human capital that occur after dissociation, but that are attributable to investments made during marriage. Such a delayed enhancement would occur, for example, in the student/non-student marriage that ends abruptly upon the student's graduation. This extraordinary case, however, is best addressed through the estimate of future earnings, which might increase the amount of "EAD." See notes 297-98 and accompanying text.

sot Fixing a lump sum requires that the number of periods be defined, because earnings will not continue indefinitely. One simple way to number future payments would be to extend them until the presumptive retirement age of the paying spouse (for example, age 65). Alternatively, the number of periods could reflect the life expectancy of a spouse, as estimated using mortality tables. While a paying spouse will not in every case continue to generate enhanced income until retirement age, this timetable would offer a simple, predictable, and litigation-free limit on the number of periods.

Another alternative would be to define the period by the length of the marriage. This limit would address the case of a spouse who, after dissociating from a brief marriage, might otherwise receive a buyout reflecting enhanced income for the life of the paying spouse. As a practical matter, however, enhancement realized from a short-term marriage is likely to be minimal since the investment period is minimal. In the extraordinary case in which a 
hanced earnings, and (3) discounting the resulting sum to present value. ${ }^{305}$ Although it is important to value the marital enterprise at the time of dissociation, it is not essential to calculate a lump-sum figure, because one might expect that in most cases a buyout will be paid as income is earned. ${ }^{306}$ Indeed, periodic payments would be the most accurate, least distortive, and perhaps only feasible option for a paying spouse, though he should be given the option of a lump-sum buyout. ${ }^{307}$

Once the marital enterprise is valued, it will in many cases become apparent that one spouse leaves the marriage with a greater share of that enterprise than the other spouse. In such cases, the spouse who takes the smaller share should receive a buyout. ${ }^{308}$

\section{Fixing the buyout price.}

If the spouses fail to fix their respective interests in the marital enterprise through a valid prenuptial agreement, equality rhetoric suggests that each spouse should presumptively take a onehalf interest. Under this approach, a dissociated spouse would take

spouse's income is greatly enhanced over the duration of a short-term marriage, concern that a dissociated spouse might reap an unreasonably large return might better be addressed by limiting the buyout share.

sos See Hamilton, Fundamentals $\$ 11.5$ at 234 (cited in note 242), for an explanation of present value calculations. See also Burke and Rosen, Valuing Educational Attainment at 69-70 (cited in note 98 ).

${ }^{308}$ An order for periodic payments should also contain some method for ensuring payment, perhaps by requiring payments through the IRS. This issue, however, must be left for another time.

${ }^{307}$ A paying spouse might elect a lump-sum buyout because he seeks the clean break this option would afford.

sos This enhanced-earnings formula will not necessarily require the higher wage earner to buy out the interest of the other spouse, and one can imagine a scenario in which the opposite result occurs. Consider a wife whose annual earnings during the marriage increased from $\$ 15,000$ to $\$ 35,000$ and a husband whose earnings increased from $\$ 80,000$ to $\$ 85,000$. Because the wife takes a larger share of the enhanced earnings, she must buy out her higher-earning husband. While this result may seem counterintuitive, it is a fair application of the principle that maintenance is an investment return rather than a need-based entitlement. The logic that one who makes a good bargain is entitled to its reward is no less compelling where the lower-wage-earner increases earnings more than the higher-wageearner.

While this scenario may rarely materialize, one could avoid its harshness on the lowerwage-earner in two ways. The first is by establishing a presumption that the spouse with the lower EAD need not buy out the other spouse's interest. The second is by establishing a presumption that "catching-up is free" so that only enhanced earnings that exceed the other spouse's earnings at the time of marriage would be subject to buyout. If, for example, the wife's earnings increased during the marriage from $\$ 15,000$ to $\$ 90,000$, and the husband's increased from $\$ 80,000$ to $\$ 95,000$, only the wife's excess enhanced earnings of $\$ 10,000$ $(\$ 90,000-\$ 80,000)$ would be subject to buyout. 
fifty percent of the marital enterprise, and any disparity in enhanced earnings should be equalized to achieve this result. Such a simple approach, however, takes no account of the length of the marriage, a factor which roughly reflects the extent of a spouse's investment. The length of the marriage, for example, defines the period over which a caretaking spouse contributed her services, perhaps of a unique and indispensable nature, to the marital unit. Moreover, the duration of the marriage for a homemaker can be expected to correlate directly with her opportunity costs.

A sound approach would be to adopt a sliding-scale buyout percentage based on the length of the marriage. Such a scale might be modeled after the Uniform Probate Code ("UPC"), which bases a spouse's elective share of an augmented estate on the length of the marriage.$^{309}$ Interestingly, the drafters of this sliding-scale percentage, added in 1990, label it "the first step in the overall plan of implementing a partnership or marital-sharing theory of marriage, with a support theory back-up." 310 Using the UPC as a model, a spouse who dissociated from a marriage of fifteen years or more would receive fifty percent of any disparity in enhanced earnings. A spouse who dissociated from a ten-year marriage would receive thirty percent of any such disparity, and a spouse who dissociated from a five-year marriage would receive fifteen percent of any such disparity. The amount of a buyout could then be easily calculated using the following formula:

${ }^{309}$ See Uniform Probate Code § 2-201, 8 ULA 88-89 (West 1983 \& Supp 1992), which establishes the following sliding scale:
If the decedent
and the spouse were
married to each other:
Less than $1 \mathrm{yr}$

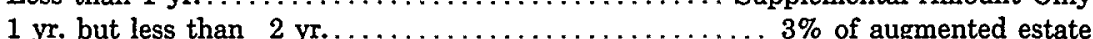
$2 \mathrm{yr}$. but less than $3 \mathrm{yr} . \ldots \ldots \ldots \ldots \ldots \ldots \ldots \ldots \ldots \ldots \ldots \ldots$ of augmented estate
$3 \mathrm{yr}$. but less than $4 \mathrm{yr} . \ldots \ldots \ldots \ldots \ldots \ldots \ldots \ldots \ldots \ldots . \ldots \ldots$ of augmented estate
4 yr. but less than 5 yr. ....................... $12 \%$ of augmented estate
$5 \mathrm{yr}$. but less than 6 yr. . . . . . . . . . . . . . . . . .
6 yr. but less than 7 yr......................



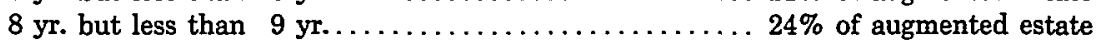

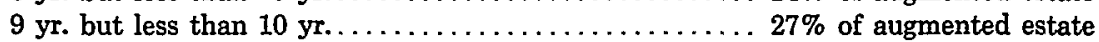
$10 \mathrm{yr}$. but less than 11 yr. . . . . . . . . . . . . . . . . .

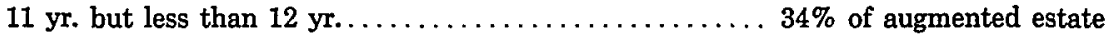

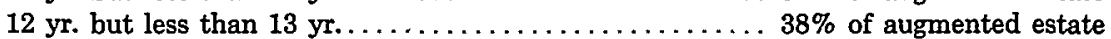
$13 \mathrm{yr}$. but less than $14 \mathrm{yr} . \ldots \ldots \ldots \ldots \ldots \ldots \ldots \ldots \ldots \ldots \ldots \ldots \ldots$ of augmented estate
$14 \mathrm{yr}$. but less than $15 \mathrm{yr} . \ldots \ldots \ldots \ldots \ldots \ldots \ldots \ldots \ldots, \ldots \ldots$ of augmented estate
$15 \mathrm{yr}$. or more $\ldots \ldots \ldots \ldots \ldots \ldots \ldots \ldots \ldots \ldots \ldots \ldots \ldots \ldots \ldots \ldots \ldots$ of augmented estate
310 Id at 89 (Comment). 
Where,

$\mathrm{D}=$ Disparity in enhanced earnings

$\mathrm{BS}=$ Buyout Share (a percentage based on the length of the marriage)

$\mathrm{D} \times \mathrm{BS}=$ Buyout

Thus, if the husband's net enhanced earnings were $\$ 100,000$, the wife's net enhanced earnings were $\$ 50,000$, and the Buyout Share were fifty percent (marriage of fifteen years or more), the wife's buyout would be:

$$
\begin{aligned}
& \mathrm{D}=\$ 100,000-\$ 50,000=\$ 50,000 \\
& \mathrm{BS}=.50 \\
& \mathrm{~B}=\$ 50,000 \times .50=\$ 25,000
\end{aligned}
$$

This wife would receive a buyout of $\$ 25,000$ per year.

\section{Modifying a buyout.}

The valuation of the marital enterprise, which forms the basis of a buyout, focuses on the spouses' abilities to generate an enhanced stream of payments. This focus resembles the traditional focus of a maintenance award and raises similar problems of predictability. Because it is impossible to predict a future stream of enhanced earnings with absolute certainty, equity requires that a buyout be modifiable upon a substantial change in circumstance, ${ }^{311}$ such as the paying spouse's death, ${ }^{312}$ retirement, ${ }^{313}$ or loss of employment. The loss of income resulting from such factors is a risk assumed to some extent by any investor. If any of these circumstances occurs, reducing or eliminating buyout installments might

312 See, for example, UMDA § 316(a), 9A ULA 489-90 (West 1987), providing that maintenance may be modified "only as to installments accruing subsequent to the motion for modification and only upon a showing of changed circumstances so substantial and continuing as to make the terms unconscionable."

312 The likelihood that a paying spouse will die at a specified time might, of course, be factored into the definition of the number of periods by using actuarial tables. See Renick, Spousal Contribution at 63 (cited in note 97). For a discussion defining the number of periods, see note 304 .

s1s The possibility that a spouse might seek early retirement simply to avoid buyout payments raises legitimate concern. On the other hand, to require a spouse to continue buyout payments despite early retirement might well spark cries of human bondage. One way to accommodate these competing concerns might be to require a retiring spouse to pay the dissociated spouse a percentage of pension benefits reflecting the buyout share. Thus, a spouse who was paying $50 \%$ of the disparity in enhanced earnings as a buyout might begin to pay $50 \%$ of enhanced pension benefits upon early retirement as part of the division of property. 
be appropriate. In any case in which a change in circumstance triggers distribution of pension benefits to the paying spouse, the receiving spouse should share in these enhanced benefits, though the amount of buyout payments will likely be reduced to reflect the reduced income. ${ }^{314}$

An increase in the income of a paying spouse after dissociation, however, should not trigger an increase in the buyout, which, in the ordinary case, is measured by enhancement in human capital that accrues during marriage and not after dissociation. While in some cases increased income after divorce is actually a delayed return on a marital investment, the likely difficulty of establishing this connection, together with the need for finality, counsel against opening the door to upward modification. Of course, when a delayed return on marital investments is foreseen at the time of dissociation, it may be factored into the estimate of future earnings. ${ }^{315}$

Neither should the remarriage of a receiving spouse trigger a modification. ${ }^{316} \mathrm{~A}$ buyout represents a return on an investment, not aid to the needy. It would be ludicrous to contend that a commercial partner should receive a reduced buyout because she is financially secure. It is equally ludicrous to make this argument in the case of a marital enterprise.

Buyout installments might also cease upon the death of the receiving spouse. ${ }^{317}$ While termination on this ground might seem inconsistent with the earned-investment nature of a buyout, it may be necessary to ensure that buyouts are characterized as maintenance rather than property for income tax and bankruptcy purposes. ${ }^{318}$

314 The distribution of pension benefits as part of the division of marital property should be coordinated with the buyout. For a recent review of the valuation and distribution of pension benefits upon dissociation, see generally Note, 88 Colum L Rev at 194 (cited in note 90 ). For an analytical framework, see generally Blumberg, 33 UCLA L Rev at 1250 (cited in note 90 ).

315 See text accompanying notes 295-99.

318 But see UMDA $\S 316($ b), 9A ULA 490 (West 1987) ("Unless otherwise agreed in writing or expressly provided in the decree, the obligation to pay future maintenance is terminated upon the death of either party or the remarriage of the party receiving maintenance.").

317 See id.

s18 Maintenance payments are included in the gross income of the recipient and deducted from the income of the payor. See Internal Revenue Code, 28 USC $\$ \S 71,215$. It may be in the best interest of the receiving spouse to characterize a buyout as maintenance, because a paying spouse cannot discharge a maintenance obligation in bankruptcy, but can discharge a property order. 


\section{ConcLusion}

For too long, no-fault divorce laws have served as a "handy vehicle for the summary disposal of old and used wives."319 Nofault laws that authorize divorce at will place all women who assume primary caretaking responsibilities in jeopardy. No-fault mistakenly assumes that the division of property and little, if any, maintenance will afford equity to these women. The broad discretion given trial courts exacerbates this mistake, by inviting unrealistic and gender-biased views of a homemaker's opportunities for rehabilitation and self-support. Divorce has thus become an economic catastrophe for homemakers.

Often attributing this disaster to no-fault's partnership model of marriage, concerned legal scholars have searched for a better model of marriage that will provide a basis for maintenance. While their efforts have laid important groundwork, none has identified a model that provides a satisfactory basis for maintenance in the ordinary case of a wife whose role as primary caretaker limits her career options and advancement, and thus reduces her post-divorce income.

In this Article, I advocate a new model of marriage based on contemporary partnership law. Under this model, divorce occurs when a spouse dissociates from the marriage before expiration of the term. Dissociation ends the relationship, but it does not usually end the spouses' shared enterprise, which continues to generate income in the hands of one or both spouses. The spouse who takes the smaller portion of the marital enterprise-that is, the spouse who earns less-should receive a buyout. Most often, this buyout rule will require a husband to pay maintenance to a wife who served as primary caretaker. To implement a buyout rule, I offer a simple mathematical model for legislative reform that limits trial court discretion. It is my hope that this effort will help to halt the financial exploitation of caretakers under no-fault, and so contribute to the effort of the American Law Institute to formulate a set of principles that brings integrity to the law of divorce. 
